\title{
ITCZ Width Controls on Hadley Cell Extent and Eddy-Driven Jet Position and Their Response to Warming
}

\author{
Oliver WATt-MEYer AND DARGAN M. W. FrIERSON \\ Department of Atmospheric Sciences, University of Washington, Seattle, Washington
}

(Manuscript received 3 July 2018, in final form 30 November 2018)

\begin{abstract}
The impact of global warming-induced intertropical convergence zone (ITCZ) narrowing onto the higherlatitude circulation is examined in the GFDL Atmospheric Model, version 2.1 (AM2.1), run over zonally symmetric aquaplanet boundary conditions. A striking reconfiguration of the deep tropical precipitation from double-peaked, off-equatorial ascent to a single peak at the equator occurs under a globally uniform $+4 \mathrm{~K}$ sea surface temperature (SST) perturbation. This response is found to be highly sensitive to the SST profile used to force the model. By making small $(\leq 1 \mathrm{~K})$ perturbations to the surface temperature in the deep tropics, varying control simulation precipitation patterns with both single and double ITCZs are generated. Across the climatologies, narrower regions of ascent correspond to more equatorward Hadley cell edges and eddydriven jets. Under the global warming perturbation, the experiments in which there is narrowing of the ITCZ show significantly less expansion of the Hadley cell and somewhat less poleward shift of the eddy-driven jet than those without ITCZ narrowing. With a narrower ITCZ, the ascending air has larger zonal momentum, causing more westerly upper-tropospheric subtropical wind. In turn, this implies 1) the subtropical jet will become baroclinically unstable at a lower latitude and 2) the critical (zero wind) line will shift equatorward, allowing midlatitude eddies to propagate farther equatorward. Both of these mechanisms modify the Hadley cell edge position, and the latter affects the jet position.
\end{abstract}

\section{Introduction}

Substantial changes to the zonal-mean atmospheric circulation are expected as a response to global warming. In some cases, there is good agreement on the expected sign of the response. For example, in the subtropics and extratropics, poleward expansion of the Hadley cell edge (Fu et al. 2006; Lu et al. 2007; Seidel and Randel 2007; Seidel et al. 2008), jet stream position (Kushner et al. 2001), and storm track latitude (Yin 2005) are all expected with climate change. These changes are projected to occur based on comprehensive climate models (Lu et al. 2007; Barnes and Polvani 2013; Simpson et al. 2014), and poleward Hadley cell edge shifts have been observed to occur in recent observations (Fu et al. 2006; Seidel and Randel 2007; Seidel et al. 2008; Davis and Birner 2017). These expansions are generally thought to be due to the amplified warming in the tropical upper troposphere, which increases the static stability in the subtropics ( $\mathrm{Lu}$ et al. 2007; Frierson et al. 2007) and increases the equator-to-pole

Corresponding author: Oliver Watt-Meyer, oliverwm@uw.edu temperature gradient in the upper troposphere (Chen and Held 2007; Butler et al. 2010).

Expected changes in the deep tropical circulation as a result of global warming are more uncertain. While the multimodel mean of the zonal-mean precipitation and vertical ascent response to global warming in the tropics suggests a narrowing of the intertropical convergence zone (ITCZ; Lau and Kim 2015; Byrne and Schneider 2016a) due to increased moist static energy gradients, not all models agree on the sign of this response (Byrne and Schneider 2016a). Meridional shifts of the ITCZ position are also possible with climate change due to factors such as aerosol cleanup, cloud feedbacks, and changes in ocean circulation (Allen et al. 2015; Rotstayn et al. 2015; McFarlane and Frierson 2017) but these shifts are small in the multimodel mean projection of twenty-first century climate change (Byrne et al. 2018). In the recent observational record, a narrowing of the annual-mean ITCZ in both the Pacific (Wodzicki and Rapp 2016) and Atlantic (Byrne et al. 2018) has been reported.

Changes in the Hadley cell edge and eddy-driven jet position are not independent of changes in the deep 

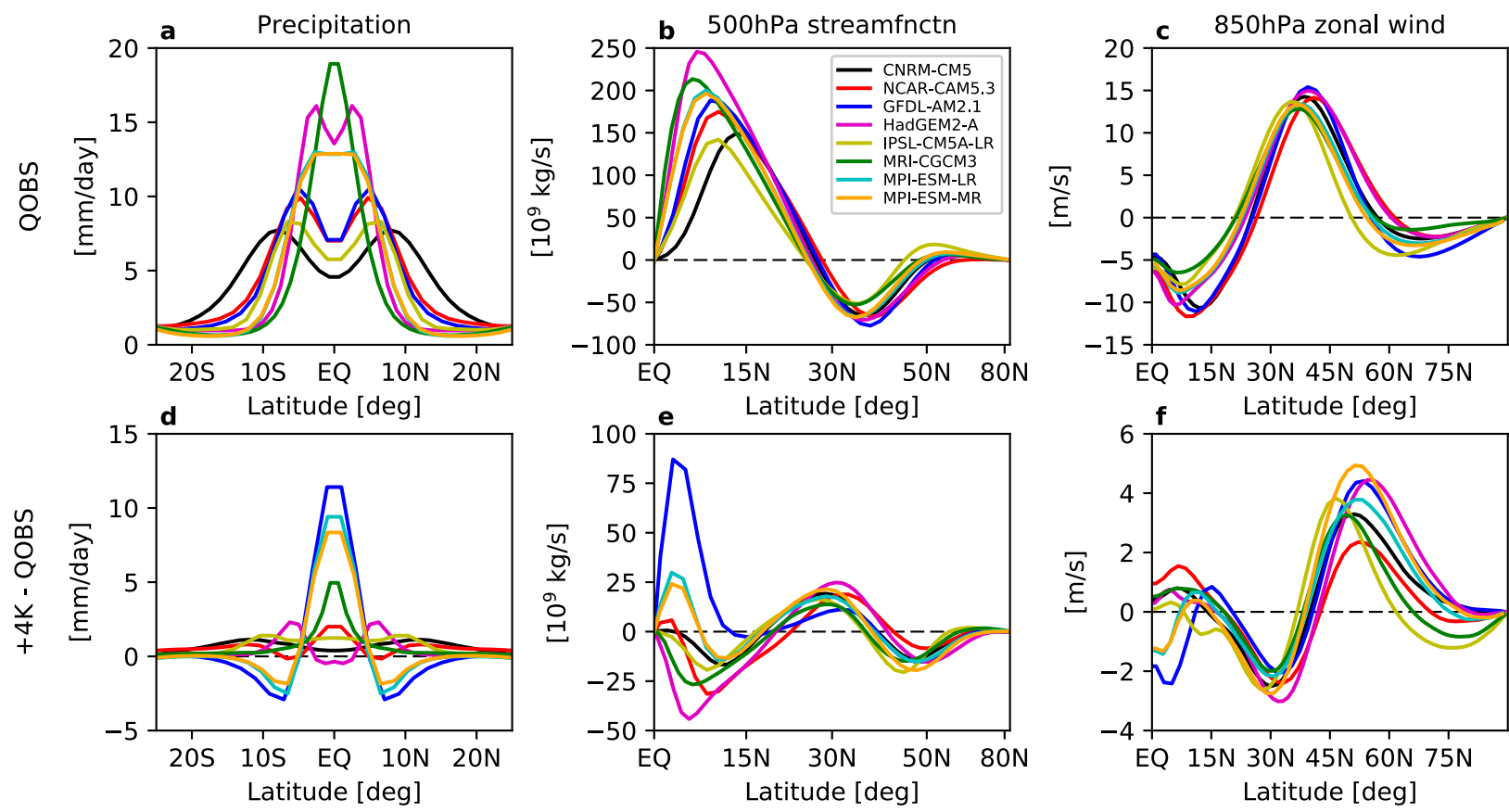

FIG. 1. The time- and zonal-mean (left) tropical precipitation, (middle) 500-hPa mass streamfunction, and (right) 850-hPa zonal wind from eight aquaplanet models. (top) Simulations performed with the QOBS SST profile (Neale and Hoskins 2000a); (bottom) the response to a globally uniform $+4 \mathrm{~K}$ SST perturbation. All data are averaged over the Southern and Northern Hemispheres, including for variables shown for both hemispheres (i.e., the precipitation).

tropical circulation. El Niño events provide a natural case study for tropically driven influence on the zonally averaged extratropical circulation. During El Niño events, tropical rainfall concentrates more closely on the equator and the Hadley cell accelerates (e.g., Fig. 5 of Adames and Wallace 2017; Seager et al. 2003). This shift and contraction of precipitation is thought to occur because of increased energy input to the atmosphere near the equator (Bischoff and Schneider 2014; Adam et al. 2016). Two factors lead to an increase in zonal winds within the upper branch of the Hadley cell: an equatorially confined updraft means that the angular momentum of the rising air is larger (since the distance to the rotation axis $a \cos (\phi)$ is maximal at the equator), and a stronger Hadley cell leads to winds that more closely follow angular momentum conservation since eddy stresses play a lesser role in the zonal-mean wind budget. Stronger zonal winds in the tropical upper troposphere then tend to shift the Hadley cell edge and storm track location equatorward. This can be understood both because of the latitude of baroclinic instability onset being shifted equatorward (Held et al. 2000; Lee and Kim 2003) and by the critical line for Rossby wave breaking shifting equatorward (Randel and Held 1991; Ceppi et al. 2013). In accordance with this mechanism, westerly zonal winds during El Niño lead to a narrower Hadley circulation and an equatorward-shifted storm track (Seager et al. 2003; Adames and Wallace 2017). Based on this idea, it is reasonable to suppose that changes in the position, width, and strength of ascent in the deep tropics under global warming may have an impact on the higher-latitude response. Previous work has found that ITCZ position changes play a role in setting the Hadley cell edge response to warming in comprehensive climate models (Kang and Lu 2012) and in response to imposed ocean heat transport in a slab ocean aquaplanet model (Hilgenbrink and Hartmann 2018).

For phase 5 of the Coupled Model Intercomparison Project (CMIP5), aquaplanet simulations-that is, atmospheric general circulation models with no land surface or continents and forced by an idealized zonally symmetric sea surface temperature (SST) patternwere performed with a variety of models (Taylor et al. 2012). These experiments are ideal for investigating the zonally symmetric circulations of interest in this study. The impact of global warming was simulated by imposing a globally uniform $+4 \mathrm{~K}$ SST perturbation. The resulting circulations and warming responses for eight different models are shown in Fig. 1. It is evident that across these aquaplanet simulations, the midlatitude circulation responses are consistent in sign: The mass streamfunction responses consistently show a poleward shift in the edge of the Hadley cell and Ferrel cell 
(Figs. 1b,e) and the lower-tropospheric zonal wind response is always a dipole that represents a poleward shift in the maximum wind (Figs. 1c,f). However, the climatological circulations and $+4 \mathrm{~K}$ responses in the deep tropics - equatorward of $15^{\circ}$ - show remarkable variation across the models. The precipitation climatologies (Fig. 1a) vary from a wide double ITCZ with strongest precipitation at $10^{\circ} \mathrm{S} / \mathrm{N}$ (CNRM-CM5) to a single narrow maximum at the equator (MRI-CGCM3). Furthermore, the $+4 \mathrm{~K}$ changes in tropical precipitation range from widening to strong contraction of the region of maximum precipitation near the equator (Fig. 1d). Correspondingly, the deep tropical $500-\mathrm{hPa}$ mass streamfunction response varies from about $-50 \times 10^{9} \mathrm{~kg} \mathrm{~s}^{-1}$ for the HadGEM2-A model to $+85 \times 10^{9} \mathrm{~kg} \mathrm{~s}^{-1}$ for the GFDL Atmospheric Model, version 2.1 (AM2.1), model (Fig. 1e).

Given the connections between the ITCZ position/ width to both the Hadley cell edge and eddy-driven jet position discussed above and known to occur during El Niño events, we postulate that possible changes in the ITCZ width under global warming would have an impact on the higher-latitude circulation response. Specifically, a narrowing of the ITCZ (Lau and Kim 2015; Byrne and Schneider 2016a) would lead to a smaller-than-otherwise-expected poleward Hadley cell edge and eddy-driven jet shift. Furthermore, the ITCZ width changes associated with, for example, a globally uniform $+4 \mathrm{~K}$ SST perturbation in aquaplanet models are highly uncertain, not agreeing even on sign. We suggest that the varying deep tropical circulation responses contribute to the spread in higher-latitude circulation responses, which agree in sign but not quantitatively.
The rest of this paper is structured as follows: Section 2 describes the atmospheric model and experimental setup, as well as the diagnostics used to describe the atmospheric circulation. Section 3 presents the main results of the study, including the relationship between the deep tropical and higher-latitude circulation responses to global warming in a specified SST model. Section 4 provides analogous results of simulations performed with a slab ocean model. Section 5 quantifies the relationship between the deep tropical and higherlatitude circulations across the CMIP5 aquaplanet experiments. Finally, a summary and discussion of results is provided in section 6 .

\section{Model and diagnostics}

\section{a. GFDL-AM2.1 model experiments}

The GFDL-AM2.1 model (Anderson et al. 2004) is used at $2^{\circ} \times 2.5^{\circ}$ resolution in a zonally symmetric aquaplanet mode with specified SSTs and following the specifications of the aquaplanet experiment (Neale and Hoskins 2000a). The primary SST profile used is the socalled QOBS profile of Neale and Hoskins (2000a), which is a simple analytic function somewhat close to the observed SST distribution in the Pacific and is the profile used for CMIP5 aquaplanet simulations shown in Fig. 1 (Taylor et al. 2012). To examine the sensitivity of the higher-latitude circulation response to deep tropical circulation changes, we perform simulations with relatively small changes to the QOBS SST profile equatorward of $20^{\circ}$ latitude in order to generate varying basic-state tropical circulations. The standard QOBS profile is given by

$$
\operatorname{SST}(\phi)= \begin{cases}27\left[1-\frac{1}{2} \sin ^{2}\left(\frac{3 \phi}{2}\right)-\frac{1}{2} \sin ^{4}\left(\frac{3 \phi}{2}\right)\right]{ }^{\circ} \mathrm{C}, & \text { if }-\frac{\pi}{3}<\phi<\frac{\pi}{3} \\ 0^{\circ} \mathrm{C}, & \text { otherwise }\end{cases}
$$

and the perturbations we apply take the form

$$
\Delta \operatorname{SST}(\phi)= \begin{cases}\frac{1}{4} \Delta T_{\text {eq }}\left[1+\cos ^{2}\left(\frac{\pi}{2} \frac{\phi}{\Delta \phi}\right)\right]^{2} \mathrm{~K}, & \text { if }-\Delta \phi<\phi<\Delta \phi \\ 0 \mathrm{~K}, & \text { otherwise }\end{cases}
$$

where $\Delta T_{\text {eq }}$ is the size of the SST perturbation at the equator and $\Delta \phi$ is the meridional extent of the perturbation. For the experiments in this study, $\Delta \phi=\pi / 9=20^{\circ}$ and $\Delta T_{\text {eq }}=-0.5,-0.25,0,0.25,0.5$, and $1 \mathrm{~K}$. See Fig. $2 \mathrm{a}$ for the six SST profiles used, which will be collectively referred to as the "control" experiments. To simulate the impacts of global warming on the atmospheric circulation, the same globally uniform $+4 \mathrm{~K}$ perturbation is applied to each of the six SST profiles, which themselves vary only in terms of $\Delta T_{\text {eq }}$.

Simulations are 20 years long for each experiment, after a 1-yr spinup. All quantities shown are for the time 
a) SST

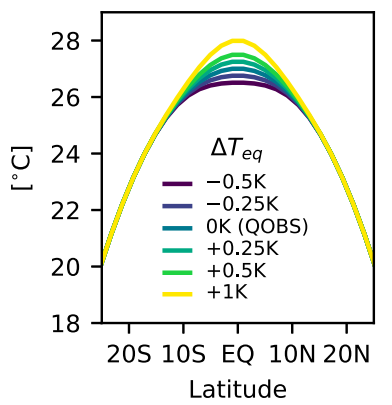

b) Precipitation

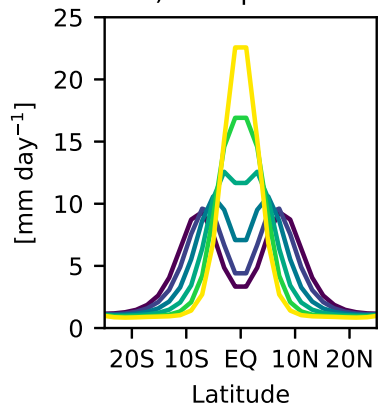

c) $500 \mathrm{hPa}$ streamfnct

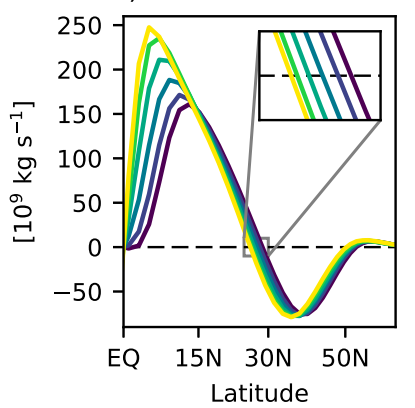

c) $850 \mathrm{hPa}$ zonal wind

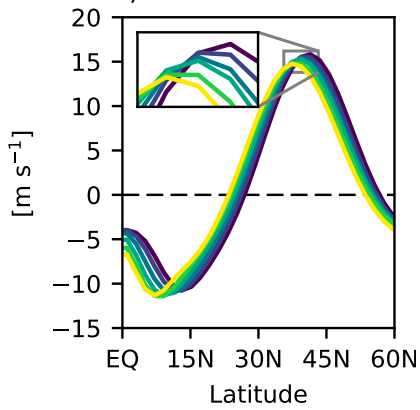

FIG. 2. The time- and zonal-mean (a) SST, (b) tropical precipitation, (c) 500-hPa mass streamfunction, and (d) 850-hPa zonal wind for the six experiments with differing $\Delta T_{\text {eq }}$. For (a), only the tropics are shown, but poleward of $20^{\circ}$ all SST profiles are the same and take the form of the QOBS profile [Eq. (1)].

and zonal mean. Since the SST profiles used are symmetric across the equator, the output is averaged across the two hemispheres before the circulation diagnostics are computed. All results are similar for the individual Southern and Northern Hemisphere data. Experiments with the same atmospheric model coupled to a slab ocean will be described in section 4 .

\section{b. Circulation metrics}

We will use the Hadley cell extent and latitude of the eddy-driven jet as metrics for the subtropical and midlatitude zonal-mean atmospheric circulation. Following previous work, we define the Hadley cell extent as the first zero crossing of the $500-\mathrm{hPa}$ mass streamfunction poleward of its tropical extremum (e.g., Frierson et al. 2007) and label it $\phi_{\mathrm{hc}}$. It is computed by linearly interpolating between the grid points on either side of the zero crossing. The eddydriven jet position is defined as the latitude of the maximum zonal-mean zonal wind at $850 \mathrm{hPa}$ and is labeled $\phi_{\text {jet }}$. It is computed by fitting a quadratic polynomial to the wind at the grid point of maximum wind and the two adjacent points on each side (Simpson and Polvani 2016). The width of the ITCZ, that is, the ascending portion of the Hadley circulation, is defined as the distance between the equator and the maximum of the streamfunction at $500 \mathrm{hPa}$ and is labeled $\phi_{\text {itcz }}$ [as in Byrne and Schneider (2016a), except we use the $500 \mathrm{hPa}$ level instead of $700 \mathrm{hPa}$ ]. This is the region of time-mean ascent, assuming there is no region of descent at the equator, which is true for all of the simulations considered in this study. We can measure the width of the ITCZ as the distance from the equator because of the hemispheric symmetry of the experiments considered. The width of the descending portion of the Hadley cell $\phi_{\text {desc }}$ is computed as the difference between the Hadley cell extent and the ITCZ width: $\phi_{\text {desc }}=\phi_{\text {hc }}-\phi_{\text {itcz. }}$. The Hadley cell strength is defined as the maximum value of the mass streamfunction and is labeled $\Psi_{\max }$.

\section{c. CMIP5 aquaplanet experiments}

Although not the primary focus of this work, results from a multimodel comparison of aquaplanet experiments will be briefly discussed. These data were shown in Fig. 1 and consists of six models from the CMIP5 archive that provided the necessary data (CNRM-CM5, HadGEM2-A, IPSL-CM5A-LR, MRI-CGCM3, MPI-ESM-LR, and MPI-ESM-MR) and additional data from equivalent experiments that were performed by the authors using the GFDL-AM2.1 (Anderson et al. 2004) and the NCAR CAM5.3 models (Neale et al. 2012). All eight of these experiments use the QOBS SST profile and otherwise follow specifications from the aquaplanet experiment (Neale and Hoskins 2000a; Taylor et al. 2012).

\section{Specified SST simulation results}

\section{a. Control experiment climatologies}

Using the QOBS SST profile, the GFDL-AM2.1 model simulates a double ITCZ with precipitation maximized around $5^{\circ} \mathrm{S} / \mathrm{N}$ (Fig. 1a, blue line). This is despite the maximum surface temperature being at the equator. This double-ITCZ structure also occurs in other aquaplanet models with the QOBS SST profile (e.g., Fig. 1a; Neale and Hoskins 2000b; Möbis and Stevens 2012; Oueslati and Bellon 2013; Medeiros et al. 2016). Its existence can be dependent on the convection scheme used and the vertical, horizontal, and temporal resolutions (Williamson 2008; Möbis and Stevens 2012; Retsch et al. 2017) and is a result of complex feedbacks between surface winds, evaporation, and convective heating (Möbis and Stevens 2012; Oueslati and Bellon 2013). For the GFDL-AM2.1 model, this double-ITCZ pattern is highly sensitive to the exact SSTs in the deep tropical region. In particular, the SST perturbations of 
TABLE 1. Climatological values (first number in each entry) of Hadley cell strength $\psi_{\max }$, ITCZ width $\phi_{\text {itcz }}$, Hadley cell width $\phi_{\text {hc }}$, and eddy-driven jet position $\phi_{\text {jet }}$ for the six control experiments, and the response (in parentheses) to the globally uniform $+4 \mathrm{~K}$ SST perturbation. The final column shows the annular mode time scale $\tau_{\mathrm{AM}}$ and its uncertainty for each control experiment, computed as in Gerber et al. (2008).

\begin{tabular}{|c|c|c|c|c|c|}
\hline Experiment & $\psi_{\max }\left(10^{9} \mathrm{~kg} \mathrm{~s}^{-1}\right)$ & $\phi_{\text {itcz }}\left({ }^{\circ} \mathrm{N}\right)$ & $\phi_{\mathrm{hc}}\left({ }^{\circ} \mathrm{N}\right)$ & $\phi_{\text {jet }}\left({ }^{\circ} \mathrm{N}\right)$ & $\tau_{\mathrm{AM}}$ [days] \\
\hline$\Delta T_{\mathrm{eq}}=-0.5 \mathrm{~K}$ & $175(-2.3)$ & $13.4(-0.2)$ & $28.7(+1.3)$ & $41.1(+2.2)$ & $50 \pm 6$ \\
\hline$\Delta T_{\mathrm{eq}}=-0.25 \mathrm{~K}$ & $185(+4.6)$ & $12.0(-1.2)$ & $28.1(+0.8)$ & $40.3(+1.7)$ & $55 \pm 7$ \\
\hline QOBS & $200(+23.8)$ & $10.2(-2.3)$ & $27.4(+0.7)$ & $39.6(+2.3)$ & $54 \pm 7$ \\
\hline$\Delta T_{\mathrm{eq}}=+0.25 \mathrm{~K}$ & $221(+12.6)$ & $8.4(-1.1)$ & $26.8(+1.1)$ & $39.2(+2.6)$ & $52 \pm 6$ \\
\hline$\Delta T_{\mathrm{eq}}=+0.5 \mathrm{~K}$ & $247(-8.8)$ & $7.5(-0.5)$ & $26.3(+1.6)$ & $38.4(+3.0)$ & $60 \pm 8$ \\
\hline$\Delta T_{\mathrm{eq}}=+1 \mathrm{~K}$ & $260(-19.4)$ & $6.3(0.0)$ & $26.0(+1.8)$ & $37.8(+3.3)$ & $60 \pm 8$ \\
\hline
\end{tabular}

Eq. (2) cause fundamental reorganizations of the tropical circulation (and its response to warming, although discussion of this is delayed until the next section). The QOBS and flatter distributions, $\Delta T_{\text {eq }}=-0.5$ or $-25 \mathrm{~K}$, have a double-ITCZ circulation with strongest vertical ascent well off the equator (between $5^{\circ}$ and $7^{\circ} \mathrm{S} / \mathrm{N}$ ) whereas those simulations with a more peaked SST profile, $\Delta T_{\mathrm{eq}} \geq 0.5 \mathrm{~K}$, have their largest ascent on the equator (Figs. 2b,c). This range of tropical precipitation patterns roughly spans the range simulated by the eight different models run with the QOBS SST profile (Fig. 1a).

As the deep tropical circulation varies with $\Delta T_{\text {eq }}$, there are also significant changes in the subtropical and midlatitude circulations. With the ITCZ narrowing and the Hadley cell strengthening, the Hadley cell extent decreases (Fig. 2c) and the eddy-driven jet shifts equatorward (Fig. 2d). This is analogous to the observed zonal-mean response to El Niño [c.f. Figs. 4 and 5 of Adames and Wallace (2017)] and to the response of the circulation to the atmospheric cloud radiative effects of tropical clouds, which also act to narrow the ITCZ and draw the Hadley cell edge and eddy-driven jet position equatorward (Watt-Meyer and Frierson 2017). See Table 1 for the quantitative values of the key circulation parameters across the six simulations.

The mechanism for a higher-latitude response to the ITCZ narrowing and Hadley cell strengthening was discussed in the introduction and is briefly repeated here. Insofar as angular momentum is conserved, air parcels that begin their poleward flow in the upper branch of the Hadley circulation closer to the equator will gain a larger component of zonal wind (Held et al. 2000). Furthermore, a stronger Hadley cell will lead to winds that more closely follow angular momentum conservation (i.e., eddy stresses will play a relatively lesser role in the zonal-mean wind budget). Both of these factors will force a Hadley cell edge that is closer to the equator (Held et al. 2000; Kang and Lu 2012). Furthermore, a stronger subtropical jet will also in turn lead to an equatorward-shifted eddy-driven jet via changes in critical lines or the region of maximum baroclinicity (Lee and Kim 2003; Barnes and Hartmann 2011; Ceppi et al. 2013).

Indeed, as the ITCZ narrows across the control simulations, there is a significant strengthening of the subtropical jet (Figs. 3a,b) that results in an equatorward shift of the critical line separating the equatorial easterlies and higher-latitude westerlies. A simple calculation assuming the conservation of angular momentum $M=(\Omega a \cos \phi+u) a \cos \phi$ and that the zonal-mean zonal wind has a fixed value at the position of the ITCZ gives that the ITCZ shifting from $7^{\circ}$ (as in the $\Delta T_{\text {eq }}=-0.5 \mathrm{~K}$ case) to the equator will give a $7 \mathrm{~m} \mathrm{~s}^{-1}$ acceleration of the zonal-mean winds at $10^{\circ}$ latitude. While in reality the atmosphere is not exactly momentum conserving because of the impacts of eddy momentum flux convergence, the local Rossby number Ro $=-\zeta / f$ (Walker and Schneider 2006) in the upper troposphere is between 0.63 and 1 within $10^{\circ}$ of the equator for all six of the control experiments (Fig. 3c), suggesting that in these experiments the atmosphere is close to angular momentum conserving in the deep tropics. The Rossby number near the equator increases as a function of $\Delta T_{\text {eq }}$ (Fig. 3c), which is expected given the decreasing influence of eddy stresses as the Hadley cell strength increases with $\Delta T_{\text {eq }}$. Furthermore, the actual increases in the zonal wind found in the deep tropics (up to $7 \mathrm{~m} \mathrm{~s}^{-1}$ for $\Delta T_{\text {eq }}=+1 \mathrm{~K}$ relative to $\Delta T_{\text {eq }}=-0.5$ K; Fig. 3b) are similar to those expected assuming angular momentum conservation. These increases in the zonal wind in the deep tropics are then significantly amplified in the subtropics (rising to nearly $20 \mathrm{~m} \mathrm{~s}^{-1}$ ), which is consistent with the changes in eddy momentum flux convergence as a response to the shifting critical line, as will be discussed in more detail in section $3 \mathrm{c}$.

\section{b. Global warming response}

To model the effects of global warming onto the atmospheric circulation, a globally uniform $+4 \mathrm{~K}$ SST perturbation is added to each of the six experiments discussed in the previous section. The precipitation 
a) $150-225 \mathrm{hPa}$ zonal wind

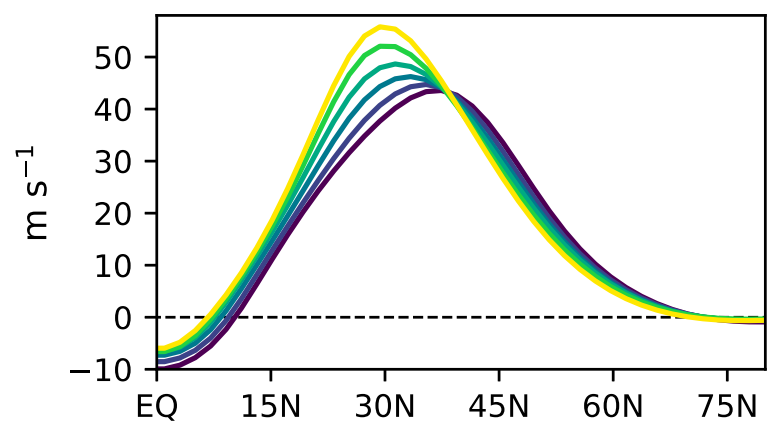

b) wind deviation from $\Delta T_{e q}=-0.5 \mathrm{~K}$

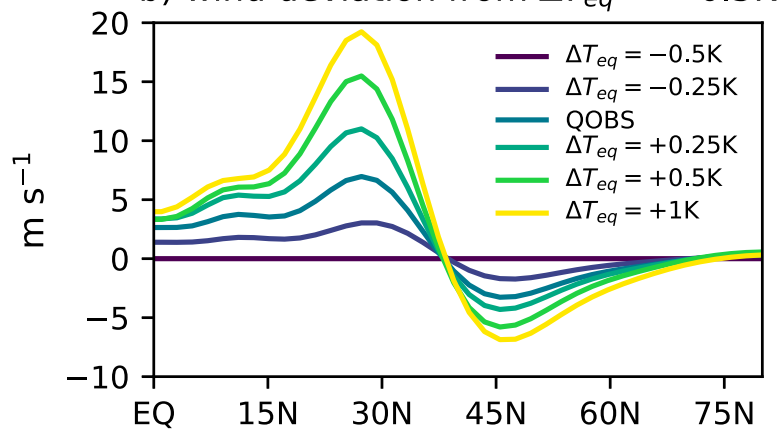

c) $150-225 \mathrm{hPa}$ Rossby number

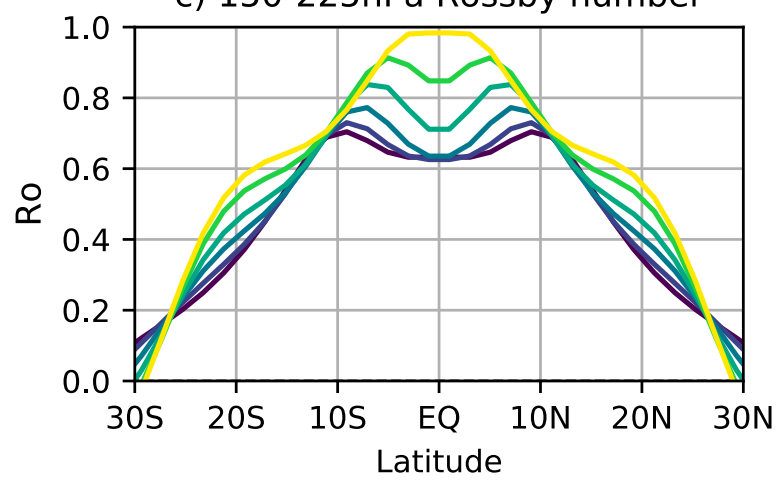

FIG. 3. (a) The time- and zonal-mean zonal wind averaged between 150 and $225 \mathrm{hPa}$ for the six experiments with differing $\Delta T_{\text {eq. }}$. (b) As in (a), but showing the difference between a particular simulation and the $\Delta T_{\text {eq }}=-0.5 \mathrm{~K}$ simulation. (c) The local Rossby number $\mathrm{Ro}=-\zeta / f$ averaged between 150 and $225 \mathrm{hPa}$.

responses to this perturbation vary strongly across the six cases (Fig. 4). For the QOBS SST profile, there is a striking rearrangement of the deep tropical circulation, with the double-ITCZ pattern being replaced by a single precipitation maximum at the equator (Fig. 4c). Comparing to other atmospheric models run with the same configuration, GFDL-AM2.1 stands out by having the largest mass streamfunction and tropical precipitation response (Fig. 1). However, when using the SST profile that is flattened near the equator $\left(\Delta T_{\text {eq }}=-0.5 \mathrm{~K}\right)$ the double-ITCZ structure remains unchanged under the $+4 \mathrm{~K}$ perturbation, and for the more peaked cases
$\left(\Delta T_{\mathrm{eq}} \geq 0.5 \mathrm{~K}\right)$, the single ITCZ of the control climate also remains unchanged. Discussion of the causes of the differing tropical circulations and responses to the $+4 \mathrm{~K}$ perturbation will be delayed until section $3 \mathrm{e}$. The focus of the remainder of this section will be on how these differing ITCZ responses to warming impact the higherlatitude circulation response.

The Hadley circulation response to the $+4 \mathrm{~K}$ SST perturbation also varies nonmonotonically as a function of the control SST profile used (Fig. 5). Corresponding to the contraction of the ITCZ seen for $-0.25 \leq \Delta T_{\mathrm{eq}} \leq 0.25 \mathrm{~K}$ cases, the mass streamfunction has a strong positive response in the region of ascent (Figs. 5b-d). The cases beginning with a more peaked SST profile show an overall weakening of the Hadley cell (Figs. 5e,f), while the flattest case has almost no response for the ascending portion of the Hadley cell or its strength (Fig. 5a). All cases show the expected poleward shift of the Hadley cell edge under the global warming perturbation (e.g., Lu et al. 2007), but the magnitude of this shift varies between experiment. For all cases, the rise of the tropopause is evident in the positive anomaly of the mass streamfunction on the upper branch of the Hadley cell.

Figure 6 shows the zonal-mean zonal wind control climatology and response for all six experiments. Qualitatively, the response is similar in all cases, with a poleward shift of the eddy-driven jet and acceleration of the westerlies on the upper flank of the subtropical jet, as expected from a rising tropopause (Santer et al. 2003; Lorenz and DeWeaver 2007), and increasing tropical to extratropical temperature gradient in the upper troposphere (Chen and Held 2007; Butler et al. 2010). However, the magnitude of the dipole in winds representing the poleward shift varies strongly between cases (e.g., cf. Figs. $6 \mathrm{~b}$ and $6 \mathrm{f})$. Furthermore, there are subtle but important differences in the response of the uppertropospheric subtropical winds between cases. The experiments that have a substantial contraction of the ITCZ and strengthening of the Hadley cell $\left(\left|\Delta T_{\mathrm{eq}}\right| \leq 0.25 \mathrm{~K}\right)$ have an acceleration of the winds on the equatorward side of the subtropical jet (from $25^{\circ}$ to $35^{\circ} \mathrm{N}$ and 200 to $400 \mathrm{hPa}$ ) that does not occur for other experiments. This is expected as a response to changes in the tropical overturning circulation (i.e., narrowing of the ITCZ and strengthening of the Hadley cell) for these cases. As discussed further in section $3 \mathrm{c}$, this change in the mean flow is concurrent with changes in eddy momentum flux, which lessen the poleward shift in the eddy-driven jet position compared to what would occur without the ITCZ narrowing.

The responses of the ITCZ width, Hadley cell edge, and eddy-driven jet in each of the six experiments are 

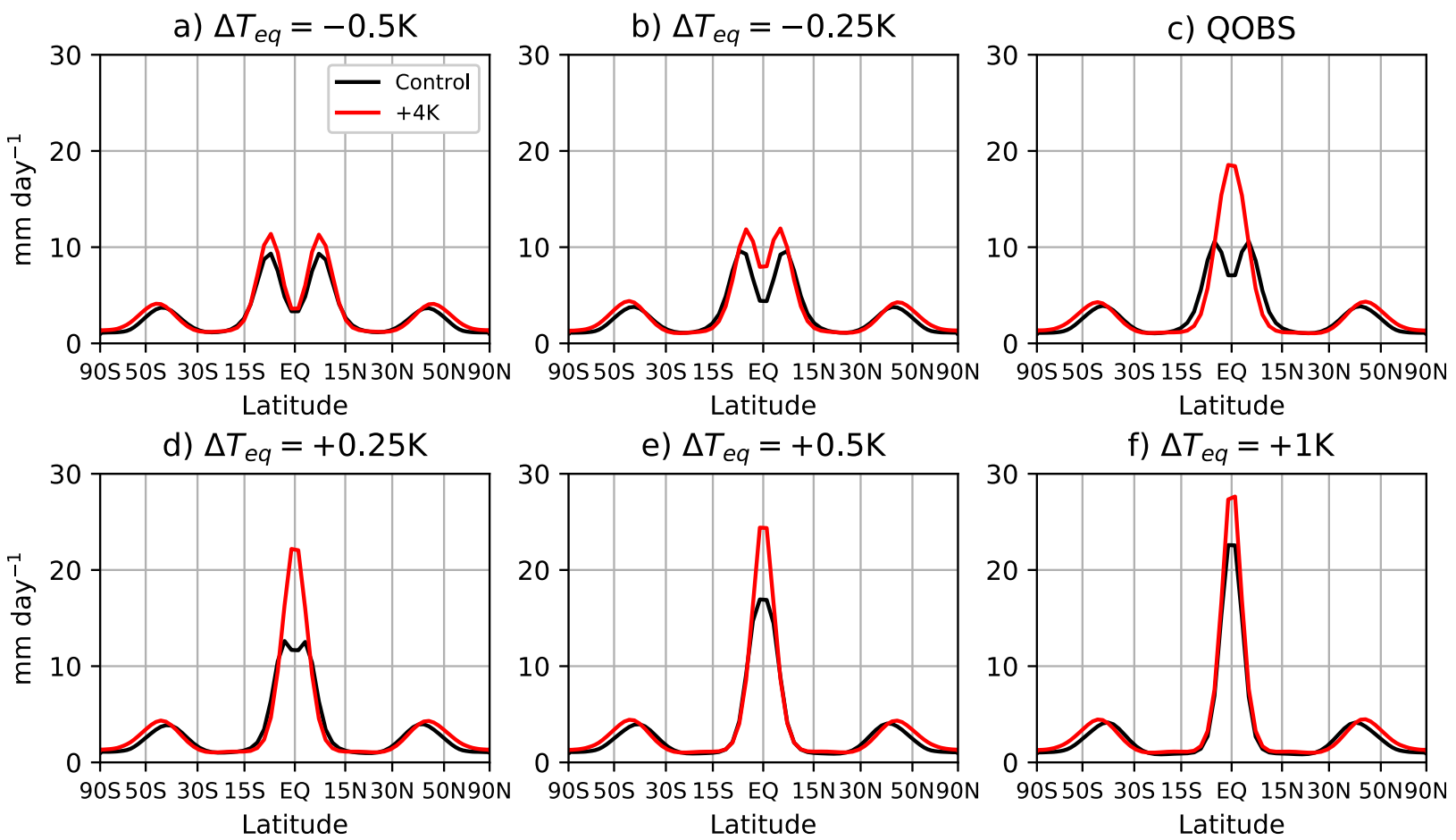

FIG. 4. Time and zonal mean of precipitation for the six different SST profiles (black; reproduced from Fig. 2b) and the same SST profiles with a globally uniform $+4 \mathrm{~K}$ perturbation (red). The $x$ axis is plotted in terms of the sine of latitude.

summarized in Fig. 7 and Table 1. This clearly demonstrates the nonmonotonicity of the ITCZ response to the $+4 \mathrm{~K}$ perturbation: The initially wide double-ITCZ and narrow single-ITCZ circulations $\left(\Delta T_{\mathrm{eq}}=-0.5 \mathrm{~K}\right.$ and $\Delta T_{\mathrm{eq}}=+1 \mathrm{~K}$, respectively), have no significant contraction of the ITCZ width under the warming perturbation, while the intermediate QOBS case has a 23\% narrowing. Furthermore, there is an approximate $10 \%$ strengthening of the Hadley cell for the QOBS case, but no significant change for the $\Delta T_{\mathrm{eq}}=-0.5 \mathrm{~K}$ case, and a roughly $8 \%$ weakening for the $\Delta T_{\mathrm{eq}}=+1 \mathrm{~K}$ case. This nonmonotonicity carries over to the Hadley cell extent: As was apparent in Fig. 5, the $+4 \mathrm{~K}$ perturbation gives a poleward shift of the Hadley cell edge for all cases, but the magnitude of the shift varies widely from $0.7^{\circ}$ poleward for QOBS, which had the strongest ITCZ narrowing, to $1.3^{\circ}$ and $1.8^{\circ}$ poleward for the $\Delta T_{\text {eq }}=-0.5 \mathrm{~K}$ and $\Delta T_{\mathrm{eq}}=1 \mathrm{~K}$, respectively. This diminished poleward shift of the Hadley cell edge for the QOBS case is consistent with the contraction of the ITCZ and Hadley cell strengthening for this case.

On the other hand, the eddy-driven jet (Fig. 7c) has its smallest response for the $\Delta T_{\text {eq }}=-0.25 \mathrm{~K}$ case instead of the QOBS case, generally increases with increasing $\Delta T_{\text {eq }}$, and has approximately the same response for the $\Delta T_{\text {eq }}=-0.5 \mathrm{~K}$ and QOBS cases. This may be because of increasing eddy feedback strength as the control jet position is closer to the equator (Kidston and Gerber 2010; Barnes et al. 2010; Simpson and Polvani 2016). Indeed, the annular mode time scale, computed as in Gerber et al. (2008), does generally increase for increasing $\Delta T_{\text {eq }}$ (Table 1) and this suggests stronger eddy feedbacks. However, because of the relatively long time scale of annular mode variability in these model experiments (e.g., $54 \pm 7$ days for the QOBS experiment), there is a large uncertainty in the time scale itself, and thus there is not a clear separation of the estimated time scale between experiments.

\section{c. Eddy momentum flux responses}

The position of the eddy-driven jet is determined by the latitude of maximum eddy momentum flux convergence. In turn, this depends on where midlatitude eddies are generated, that is, where the baroclinicity is largest, and how the eddies propagate through the atmosphere. The Hadley cell edge and strength are also partly controlled by the stresses of eddies generated in the midlatitudes (Walker and Schneider 2006). Examining the upper-tropospheric eddy momentum flux across the control experiments (Fig. 8), it is apparent that as $\Delta T_{\text {eq }}$ is increased, the eddy momentum flux reaches farther into the deep tropics (i.e., between $10^{\circ}$ and $20^{\circ}$; Fig. $8 \mathrm{a}$ ) and this results in increased eddy momentum flux convergence between $20^{\circ}$ and $40^{\circ}$. This is consistent with the 


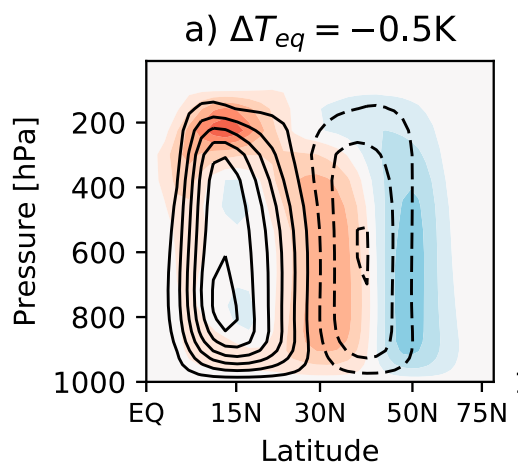

d) $\Delta T_{\text {eq }}=+0.25 \mathrm{~K}$

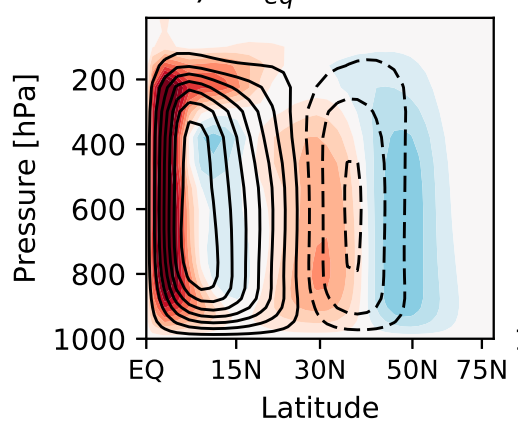

b) $\Delta T_{\text {eq }}=-0.25 \mathrm{~K}$

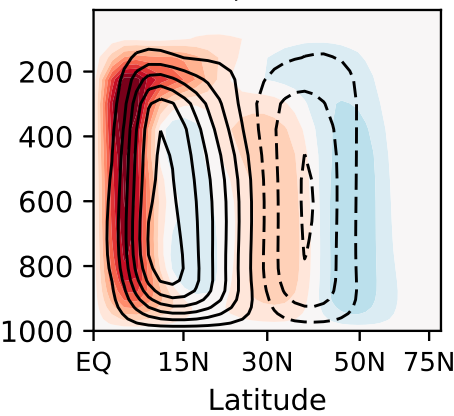

e) $\Delta T_{e q}=+0.5 \mathrm{~K}$

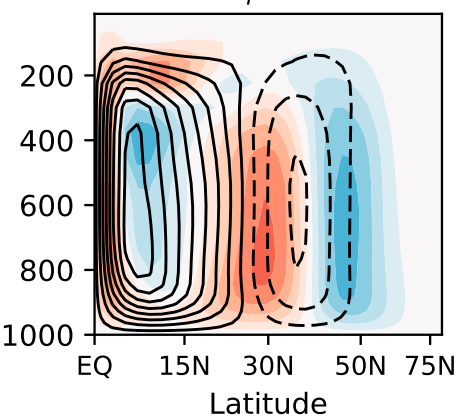

c) QOBS

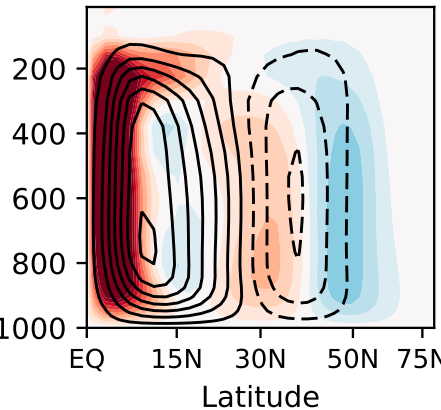

f) $\Delta T_{\text {eq }}=+1 \mathrm{~K}$

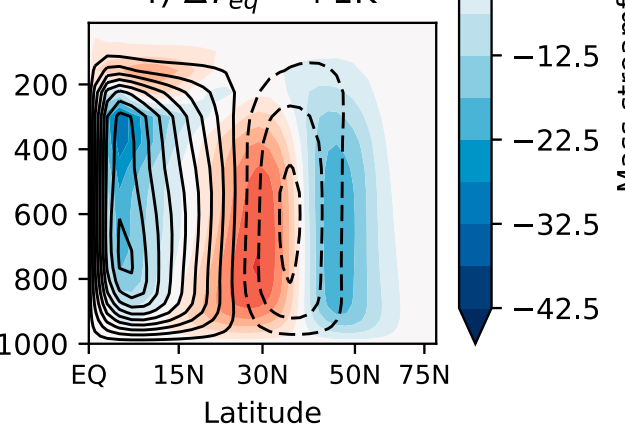

FIG. 5. Time-mean mass streamfunction for the six different SST profiles (contours) and the response of the streamfunction (shading) to a globally uniform $+4 \mathrm{~K}$ perturbation. The $x$ axis is plotted in terms of the sine of latitude and data are averaged over the Southern and Northern Hemispheres. The interval for the line contours is $30 \times 10^{9} \mathrm{~kg} \mathrm{~s}^{-1}$, starting at $\pm 15 \times 10^{9} \mathrm{~kg} \mathrm{~s}^{-1}$.

strengthening of the subtropical jet with increased $\Delta T_{\text {eq }}$ (Fig. 3) and hence equatorward shift of the critical line that determines the extent of the eddy propagation (Randel and Held 1991). Furthermore, there is a clear equatorward shift in the position of maximum convergence of eddy momentum flux, consistent with the changes in eddy-driven jet position with increasing $\Delta T_{\text {eq }}$ (Table 1).

In terms of the response of the eddy momentum flux to the $+4 \mathrm{~K}$ perturbation (Fig. $8 \mathrm{~b}$ ), the $\Delta T_{\mathrm{eq}}=+1 \mathrm{~K}$ case has the largest magnitude in the midlatitudes, corresponding to the largest poleward shift in the eddy momentum flux convergence and hence eddy-driven jet (Table 1). In the subtropics, between about $10^{\circ}$ and $25^{\circ} \mathrm{N}$, the momentum flux shows responses consistent with the critical line shifts postulated to occur with a changing ITCZ width. That is, for the QOBS case, there is an increase in the momentum flux that corresponds to eddies propagating farther into the subtropics, as expected with the strengthening of the subtropical jet as the ITCZ narrows (Fig. 6c). For the cases without ITCZ narrowing, $\Delta T_{\text {eq }}=-0.5$ and $\Delta T_{\text {eq }}=+1 \mathrm{~K}$, there is either a very weakly positive or a negative response in the eddy momentum flux. However, of these two cases, only the $\Delta T_{\mathrm{eq}}=+1 \mathrm{~K}$ one has the amplified midlatitude momentum flux response, giving the larger jet shift. As discussed in section $3 \mathrm{~b}$, this may be because of stronger eddy feedbacks for the $\Delta T_{\text {eq }}=+1 \mathrm{~K}$ case, which occur because of the more equatorward climatological position of its jet.

\section{d. ITCZ contraction and descent area expansion}

Recent work on the contraction of the ITCZ under global warming has highlighted the compensation between the ascending and descending branches of the Hadley cell: Models that simulate a greater ITCZ contraction also tend to simulate a greater expansion of the descent region of the Hadley cell (Fig. 1 of Byrne and Schneider 2016a). Given that the Hadley cell extent is the sum of the ITCZ and descent widths, this may appear to suggest that ITCZ narrowing would not impact Hadley cell width because of the compensating effect of descent region expansion. However, for the GFDLAM2.1 simulations considered in this study, although there is a strong negative linear relationship between ITCZ width and descent width (Fig. 9a), it is not a oneto-one compensation. This is made explicit in Fig. 9a by plotting lines of constant Hadley cell width (dashed lines), which are simply lines with a slope of -1 with different intercepts. It is clear that, for a given ITCZ contraction, the descending region does not widen as much and this results in a narrowing of the overall Hadley cell (Fig. 9b). This means that for the control experiments, there is a strong linear relationship between 

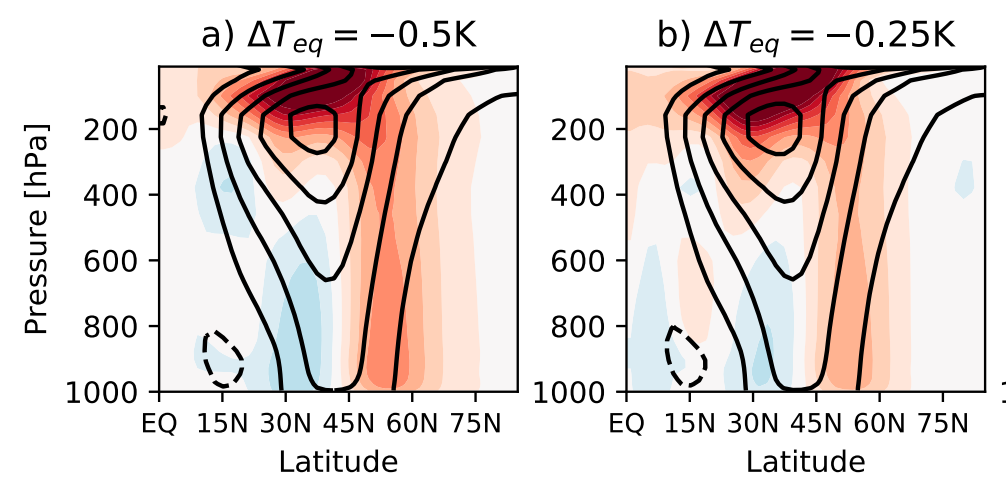

b) $\Delta T_{\text {eq }}=-0.25 \mathrm{~K}$

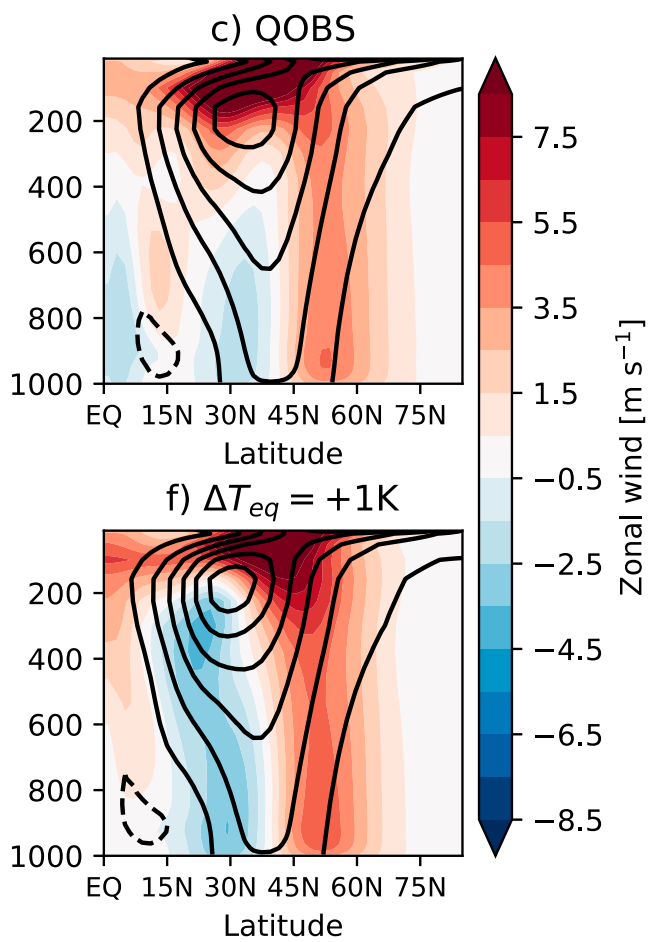

d) $\Delta T_{\text {eq }}=+0.25 \mathrm{~K}$
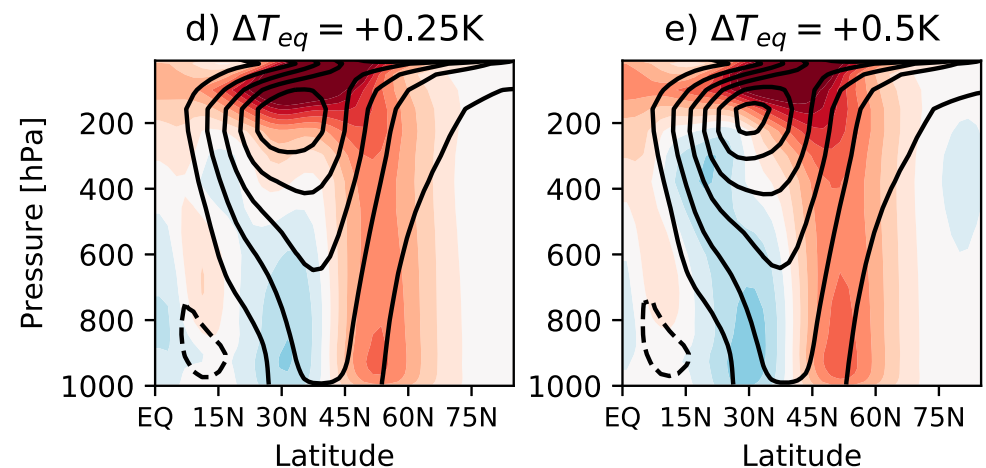

FIG. 6. As in Fig. 5, but for the zonal-mean zonal wind. The interval for the line contours is $10 \mathrm{~m} \mathrm{~s}^{-1}$.

the ITCZ width and Hadley cell extent (Pearson correlation $r=0.998)$ with a slope of $0.38^{\circ} \pm 0.01^{\circ}$ per degree. The $+4 \mathrm{~K}$ experiments also have a strong linear correlation $(r=0.99)$ and a slightly lower slope of $0.31^{\circ} \pm 0.02^{\circ}$ per degree.

A similar effect of compensation occurs when considering the responses of the atmospheric circulation to the $+4 \mathrm{~K}$ forcing (Fig. 9c). For these cases, the descent expansion is always larger than the ITCZ contraction, resulting in an expansion of the Hadley cell with global warming. However, the amount of descent area expansion is dependent on the ITCZ contraction such that there is a clear linear relationship between the ITCZ width response and Hadley cell extent response (Fig. 9d; $r=0.85$ ) with a similar slope of $0.43^{\circ} \pm 0.13^{\circ}$ per degree. In sum, the GFDL-AM2.1 simulations suggest that for each degree of ITCZ narrowing, one would expect an approximately $1 / 3^{\circ}$ contraction of the Hadley cell. The quantitative relationship between ITCZ width, descent width, and Hadley cell extent across the CMIP5 aquaplanet experiments will be shown in section 5 .

The connections between the ITCZ narrowing and eddy-driven jet shifts under the global warming perturbation are not as robust as the Hadley cell changes. Thus, although the correlation between $\phi_{\text {itcz }}$ and $\phi_{\text {jet }}$ across the control simulations is strong $(r=0.99)$, it is only $r=0.51$ when considering the $+4 \mathrm{~K}$ perturbations. As speculated in section $3 \mathrm{~b}$, it is possible the differing strengths of eddy feedbacks as the eddy-driven jet begins at differing latitudes causes some of the spread of the $+4 \mathrm{~K}$ jet response.

\section{e. Causes of different deep tropical circulations}

Although not the primary focus of this work, it is interesting to briefly consider why there are such strikingly different responses in the tropical precipitation for the different control experiments (Fig. 4). As we vary the control SST profile with the $\Delta T_{\text {eq }}$ parameter, the ITCZ and Hadley cell experience large changes. The precipitation at the equator, for instance, varies from $5 \mathrm{~mm} \mathrm{day}^{-1}$ in the $\Delta T_{\text {eq }}=-0.5 \mathrm{~K}$ case to over $20 \mathrm{~mm}$ day $^{-1}$ in the $\Delta T_{\text {eq }}=+1 \mathrm{~K}$ case (Fig. 2b). The Hadley cell strength varies by nearly a factor of 2 across this same range, and the rising branch becomes significantly more confined to the deep tropics as the equatorial SST rises (Fig. 2c). These circulation changes can be understood as a direct response to the increased SST gradient (Lindzen and Nigam 1987) or through changes in the moist static energy budget induced by the changes in surface flux and radiation (e.g., Satoh 1994).

Less expected is the large difference in response to global warming with these different control states (Fig. 4). SST gradients cannot be invoked to explain this difference among the $+4 \mathrm{~K}$ responses, and so we consider the zonal-mean atmospheric energy budget to better understand the tropical response (Fig. 10). Even 


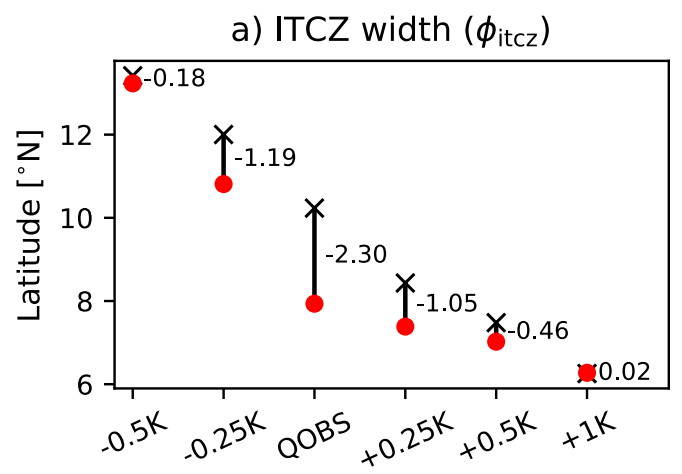

c) Hadley cell extent $\left(\phi_{\mathrm{hc}}\right)$

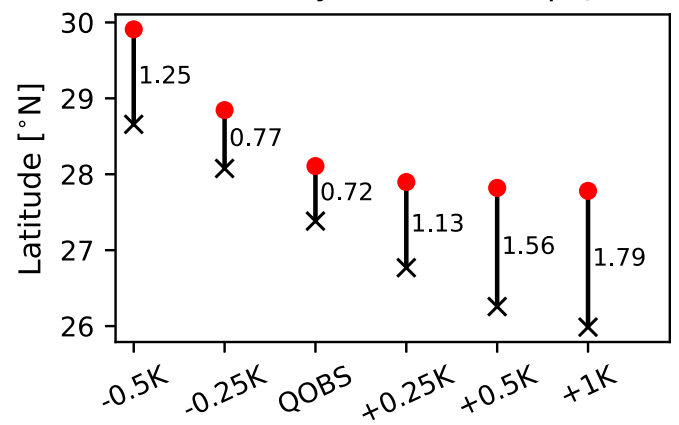

b) Hadley cell strength $\left(\Psi_{\max }\right)$

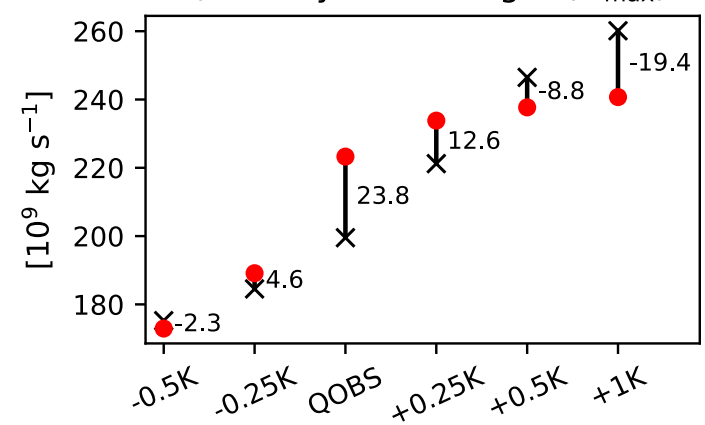

d) Eddy-driven jet latitude $\left(\phi_{\text {jet }}\right)$

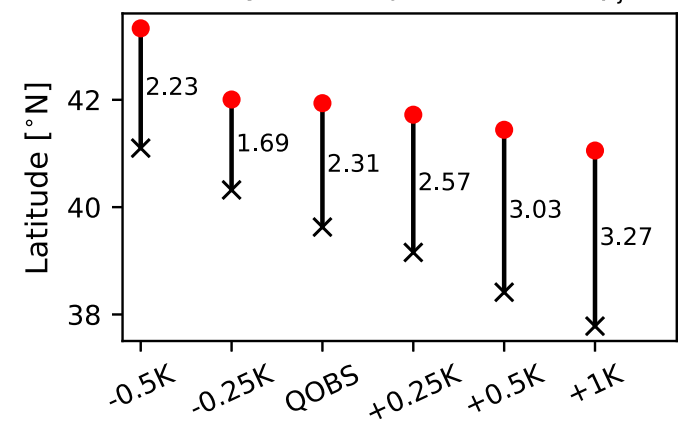

FIG. 7. The climatological (a) ITCZ width, (b) Hadley cell strength, (c) Hadley cell edge, and (d) eddy-driven jet position for the control simulations (black crosses) and $+4 \mathrm{~K}$ simulations (red circles) for all six experiments. The quantitative response of each variable for each experiment is shown in text (see also Table 1). The experiments are labeled by $\Delta T_{\text {eq }}$.

though the equator always has the warmest SST, the energy input into the atmosphere there is negative in the $\Delta T_{\text {eq }} \leq 0 \mathrm{~K}$ cases, nearly zero in the QOBS case, and positive for $\Delta T_{\text {eq }} \geq 0 \mathrm{~K}$. Previous work suggests that the circulation will form a double (single) ITCZ when there is negative (positive) energy input to the atmosphere at the equator (Bischoff and Schneider 2016), and this is consistent with our results. The responses of the energy budget to warming are distinct in the different cases. The $\Delta T_{\mathrm{eq}}=-0.5 \mathrm{~K}$ case has a nearly unchanged total energy input at the equator (Fig. 10a), which comes from a large increase in clear-sky radiative cooling being compensated by an increase in atmospheric cloud radiative effect (ACRE) and surface turbulent fluxes (not shown). In the QOBS case the change is also small, but it is such that the equatorial value goes from negative to positive (Fig. 10b), consistent with a switch from a double to single-ITCZ configuration. For this case, the increase comes from a large increase in ACRE near the equator (partially offset by an increase in clear-sky cooling) consistent with the finding that changes in clouds cause a large portion of the tropical circulation response (Voigt and Shaw 2015). In the $\Delta T_{\text {eq }}=+1 \mathrm{~K}$ case, there is a decrease in net energy input at the equator (Fig. 10c), which is driven by equatorial ACRE decreasing with warming.

For the QOBS case, it is remarkable that the mean mass circulation changes so dramatically under the $+4 \mathrm{~K}$ perturbation, while the atmospheric heating (and hence moist static energy flux) only has very small changes equatorward of $15^{\circ}$. This implies that either changes in gross moist stability or eddy fluxes must be occurring for this simulation (Kang et al. 2009; Byrne and Schneider 2016b). A more detailed examination of the causes of the tropical circulation changes (or lack thereof) under the $+4 \mathrm{~K} \mathrm{SST}$ perturbation is outside the scope of this study and left for future work.

\section{f. The $+8 K$ perturbation}

The dependency of the atmospheric circulation to the basic state in the tropics has intriguing implications for the linearity of the response to global warming perturbations of increasing magnitudes. For example, after increasing the SSTs of the QOBS case by $+4 \mathrm{~K}$, the tropical precipitation is maximized in a single peak on the equator (Fig. 4c). It might be expected that the response of the circulation to a further $+4 \mathrm{~K}$ increase in surface temperature may be more analogous to the $\Delta T_{\text {eq }}=+1$ or $\Delta T_{\text {eq }}=+0.5 \mathrm{~K}$ cases that have only one precipitation peak. To test this, a simulation was performed with a globally uniform $+8 \mathrm{~K}$ SST perturbation to the QOBS profile. The responses of the key circulation metrics, considering $\mathrm{QOBS}+4 \mathrm{~K}$ as the control state and QOBS $+8 \mathrm{~K}$ as the perturbation, are 
$150 \mathrm{hPa}-225 \mathrm{hPa}$ eddy momentum flux

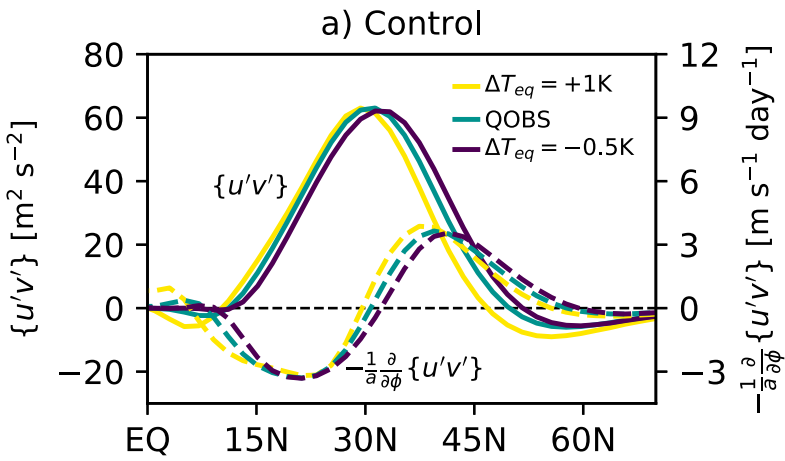

b) $+4 \mathrm{~K}$ - control

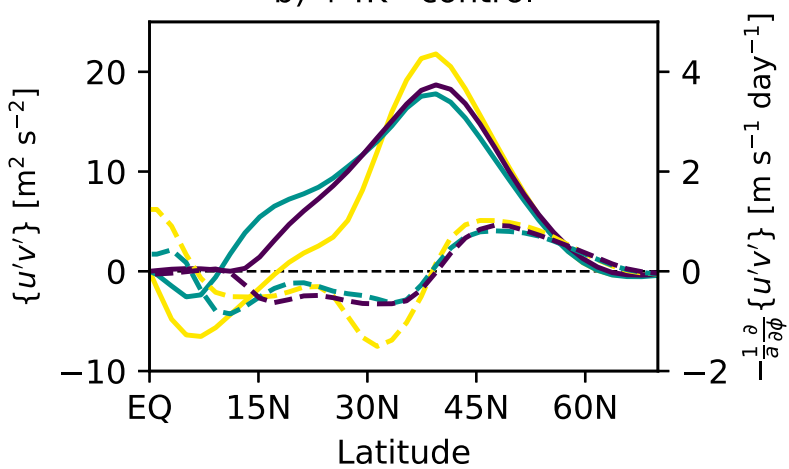

FIG. 8. Eddy momentum flux (solid) and eddy momentum flux convergence (dashed) averaged between the 150 and $225 \mathrm{hPa}$ levels for (a) three of the control experiments and (b) the response to the $+4 \mathrm{~K}$ perturbation.

$\Delta \phi_{\text {itcz }}=-0.2^{\circ}, \Delta \Psi_{\max }=-16.6 \times 10^{9} \mathrm{~kg} \mathrm{~s}^{-1}, \Delta \phi_{\mathrm{hc}}=1.3^{\circ}$, and $\Delta \phi_{\text {jet }}=3.0^{\circ}$. Comparing to the $+4 \mathrm{~K}$ response to the QOBS profile (Table 1, third line), it is apparent that there is far less ITCZ narrowing, the Hadley cell weakens instead of strengthens, and the Hadley edge and eddy-driven jet latitude shifts are larger. The larger shifts occur even though the jet is beginning at a higher latitude and thus might be expected to be less sensitive. This is another indication that the deep tropical circulation response to global warming-which nonlinearly depends on its initial state-has a significant impact on the higher-latitude response.

\section{Slab ocean simulation results}

This study primarily focuses on specified SST experiments 1) because this allows modification of the surface temperatures in the deep tropics while maintaining the same SST profile, and hence surface baroclinicity, in the higher latitudes and 2) in order to allow direct comparison to the CMIP5 aquaplanet experiments (Taylor et al. 2012). However, specified SST experiments do have a degree of unrealism because the energy is not conserved at the surface. Furthermore, the position and width of the ITCZ in models may be more sensitive to perturbations when using specified SSTs compared to a slab ocean model (e.g., Fig. 1 of Voigt et al. 2016). For this reason, additional experiments were performed with the GFDL-AM2.1 model coupled to a slab ocean. To generate varying tropical precipitation patterns, an implied ocean heat transport (OHT) from the equator to subtropics was imposed with varying strengths. Specifically, following Rose and Ferreira (2013), the OHT is given by

$$
\mathrm{OHT}=\Psi \sin (\phi) \cos (\phi)^{2 N},
$$

where $\phi$ is latitude, and $\Psi$ and $N$ are parameters setting the strength and meridional extent of the transport. For the experiments considered here, $N=8$ and $\Psi$ is varied from 10 to $20 \mathrm{PW}$. The surface heating imposed at the surface in the model is given by the convergence of the ocean heat transport. The slab ocean depth is $10 \mathrm{~m}$, and a) Climatology

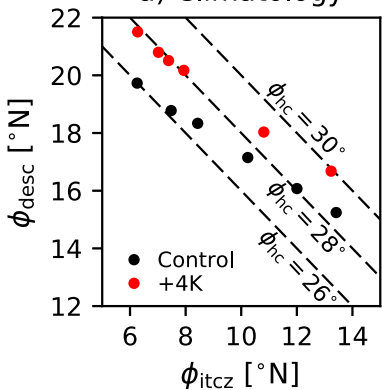

b) Climatology

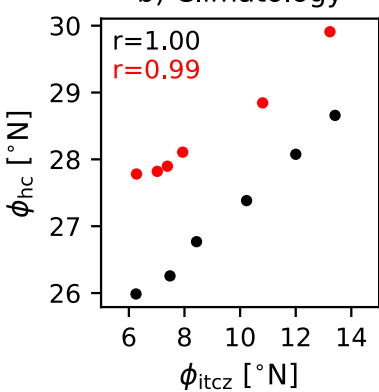

c) $+4 \mathrm{~K}$ response

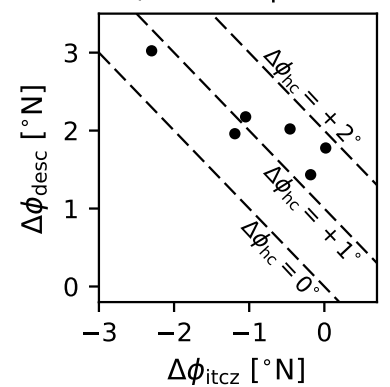

d) $+4 K$ response

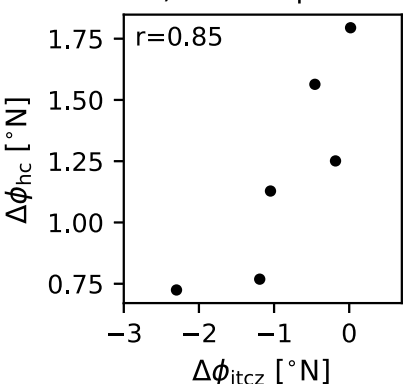

FIG. 9. The climatological (a) ITCZ width vs descent width and (b) ITCZ width vs Hadley cell extent for the six GFDL-AM2.1 experiments with varying $\Delta T_{\text {eq }}$ and the response to the $+4 \mathrm{~K} \mathrm{SST}$ perturbation for (c) ITCZ width vs descent width and (d) ITCZ width vs Hadley cell extent. In (a) and (c), contours of constant Hadley cell extent $\left(\phi_{\mathrm{hc}}=\phi_{\text {itcz }}+\phi_{\text {desc }}\right)$ are marked by dashed black lines. Pearson correlation coefficients are shown in text in (b) for the control (black) and $+4 \mathrm{~K}$ (red) simulations and in (d) for the $+4 \mathrm{~K}$ response. 

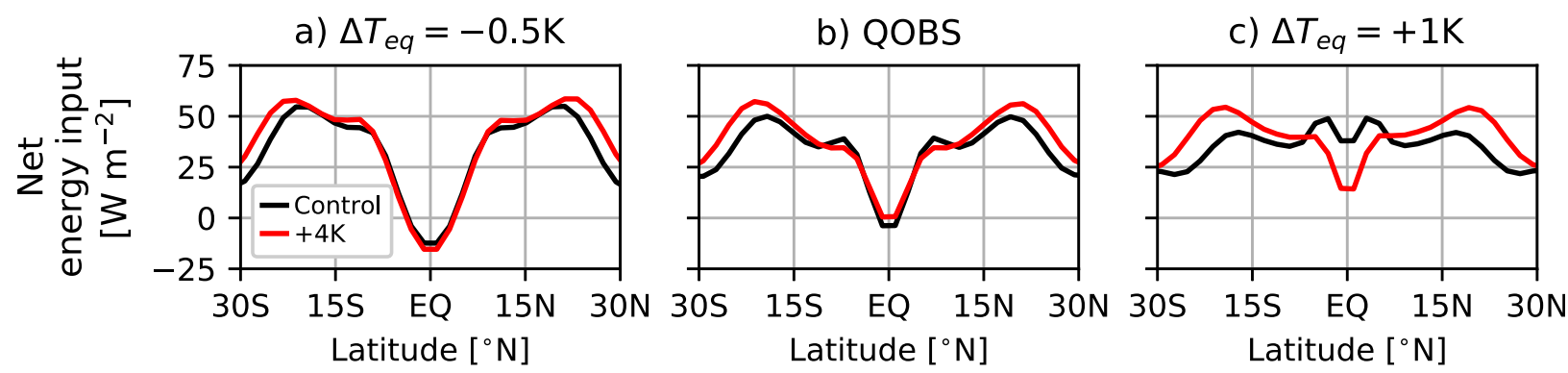

FIG. 10. Zonal-mean atmospheric energy budget in the tropics for the (a) $\Delta T_{\text {eq }}=-0.5 \mathrm{~K}$, (b) QOBS, and (c) $\Delta T_{\text {eq }}=+1 \mathrm{~K}$ experiments. Black lines represent the control SST profiles and red the $+4 \mathrm{~K}$ simulations.

the model is run with no seasonal or diurnal cycle and with annual-mean solar insolation. The global warming perturbation is imposed by quadrupling the atmospheric concentration of $\mathrm{CO}_{2}$. The simulations are run for 25 years, with the first 5 years discarded as a spinup.

By increasing the amplitude of ocean heat transport from the deep tropics to the subtropics [Eq. (3)] the SSTs become less peaked near the equator and the precipitation widens from a single maximum to a double-ITCZ pattern (not shown, but see $\phi_{\text {itcz }}$ column in Table 2). In addition, the climatological Hadley cell edge and eddy-driven jet position move poleward with the widening of the ITCZ and weakening of the Hadley cell (Table 2, third and fourth columns). Similar to the specified SST cases, the degree of narrowing of the ITCZ under the global warming perturbation is dependent on the initial width, and there is more narrowing for the double-ITCZ case $(\Psi=20 \mathrm{PW})$. While the changes in the ITCZ are relatively moderate compared to the dramatic double to single ITCZ transition that occurred for the QOBS specified SST case, the different tropical responses still impact the higherlatitude circulation in a similar way. Specifically, the initially narrow precipitation case $(\Psi=10 \mathrm{PW})$ shows a significant weakening of the Hadley cell and larger magnitude poleward shifts of the Hadley cell edge and eddy-driven jet than the other two cases (Table 2). Interestingly, there is a nonmonotonic dependence of the $4 \times \mathrm{CO}_{2}$ responses of $\phi_{\mathrm{hc}}$ and $\phi_{\text {jet }}$ on the ITCZ narrowing: the minimum responses occur for the $\Psi=15$ PW case, which has the intermediate ITCZ narrowing. However, this case does exhibit the least Hadley cell weakening of all three experiments, which is consistent with the lesser shifts of the Hadley cell edge and eddydriven jet position.

In contrast to the specified SST experiments, for the slab ocean experiments, changes in the ITCZ have a larger impact on the shift of the eddy-driven jet than the Hadley cell edge. The reason for this is left for future study, but it may be related to the fact that in the slab ocean model changes in surface temperature, and hence near-surface baroclinicity, are possible, allowing for larger changes in the eddy-driven jet position.

\section{CMIP5 aquaplanet experiments}

It was suggested in the introduction that the large spread of deep tropical responses to the globally uniform $+4 \mathrm{~K}$ perturbation in the CMIP5 aquaplanet experiments might explain part of the spread of higherlatitude responses. Here this idea is tested, focusing on the Hadley cell extent. Figure 11 shows the relationships between the ITCZ width, descent area, and total Hadley cell extent for the eight aquaplanet experiments, as well as their response to the $+4 \mathrm{~K}$ perturbation. As for the GFDL-AM2.1 experiments, there is a strong negative relationship between the ITCZ width and descent area (Fig. 11a), and its slope is such that a narrow ITCZ tends to lead to a narrower Hadley cell (Fig. 11b). However, there is more scatter in the relationships compared to the GFDL-AM2.1 results ( $r=0.52$ and $r=0.60$ for the QOBS and QOBS $+4 \mathrm{~K}$ experiments, respectively) the sensitivity of the Hadley cell edge to ITCZ width change is slightly smaller (slopes of $0.25^{\circ} \pm 0.17^{\circ}$ and

TABLE 2. Climatological values (first number in each entry) of key atmospheric circulation parameters for the three slab ocean control experiments, and the response (in parentheses) to the $4 \times \mathrm{CO}_{2}$ perturbation.

\begin{tabular}{lcccc}
\hline \hline Experiment & $\psi_{\max }\left(10^{9} \mathrm{~kg} \mathrm{~s}^{-1}\right)$ & $\phi_{\text {itcz }}\left({ }^{\circ} \mathrm{N}\right)$ & $\phi_{\mathrm{hc}}\left({ }^{\circ} \mathrm{N}\right)$ & $\phi_{\text {jet }}\left({ }^{\circ} \mathrm{N}\right)$ \\
\hline$\Psi=20 \mathrm{PW}$ & $127(-8.4)$ & $13.8(-1.5)$ & $31.6(+0.9)$ & $48.2(+0.9)$ \\
$\Psi=15 \mathrm{PW}$ & $146(-2.1)$ & $10.1(-0.7)$ & $29.6(+0.7)$ & $46.1(+0.2)$ \\
$\Psi=10 \mathrm{PW}$ & $180(-17.8)$ & $8.2(-0.2)$ & $28.0(+1.2)$ & $43.1(+2.2)$ \\
\hline
\end{tabular}



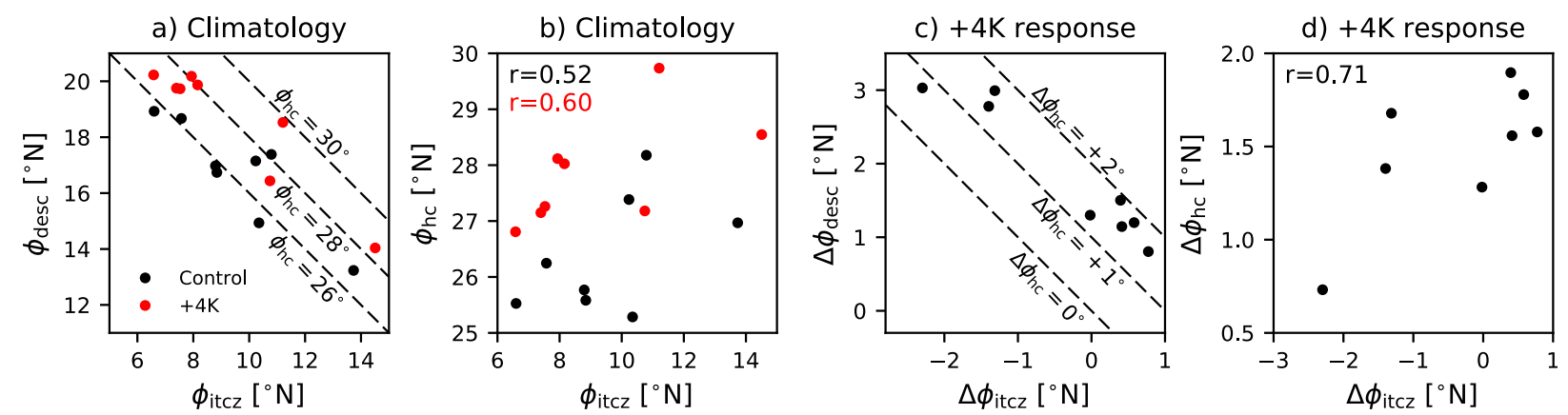

FIG. 11. As in Fig. 9, but for the eight aquaplanet simulations shown in Fig. 1.

$0.22^{\circ} \pm 0.12^{\circ}$ per degree). For the $+4 \mathrm{~K}$ responses (Figs. 11c,d) a similar relationship holds, with a correlation of $r=0.71$ and slope of $0.22^{\circ} \pm 0.99^{\circ}$ per degree. Note, however, that this correlation is dependent on the inclusion of the GFDL-AM2.1 model, which has the largest ITCZ narrowing and weakest Hadley cell expansion. Excluding the GFDL-AM2.1 model, the correlation falls to $r=0.33$.

Although with such a small sample size (eight), the correlations between the ITCZ width and Hadley cell edge are not statistically significant; they are nevertheless suggestive that the mechanism demonstrated in section 3 is relevant for explaining the spread across the aquaplanet experiments. It is not surprising that the relationships are somewhat weaker compared to the targeted GFDL-AM2.1 experiments given the many differences in the formulations of the CMIP5 models including resolution and physical parameterization choices. It would be worthwhile to examine whether differing ITCZ width changes are related to Hadley cell extent changes in fully coupled simulations of the climate response to greenhouse gas forcing.

\section{Summary and discussion}

Theories for the expansion of the tropics and poleward shift of the eddy-driven jet are generally based on the amplified warming expected in the tropical upper troposphere, which leads to increased subtropical static stability (Lu et al. 2007; Frierson et al. 2007) and equator-to-pole temperature gradients (Kushner et al. 2001; Butler et al. 2010). Less attention has been given to the impacts that momentum budget changes associated with narrowing of the region of ascent in the deep tropics have onto the shifts of the Hadley cell edge and eddy-driven jet position. This study demonstrates that differing responses in the ITCZ width and Hadley cell strength to global warming can change the Hadley cell edge response by more than a factor of 2 . This is shown with aquaplanet simulations in which the response of the
ITCZ and Hadley cell strength depends strongly on its initial state. For those in which there is a substantial ITCZ narrowing and Hadley cell strength increase under warming, the Hadley cell expansion-and to a somewhat lesser degree, eddy-driven jet shift-is less than those in which there is not. This holds in both specified SST and slab ocean experiments.

There are various implications of this effect for the expected real-world response to greenhouse gas forcing. Comprehensive models suggest a significant spread in the response of the ITCZ width to warming [e.g., Fig. 1 of Byrne and Schneider (2016a)], although the multimodel mean does indicate a contraction. The complexity of the tropical circulation response to warming is apparent even in our single-model experiments (Fig. 4). Regardless of the reason for the varying tropical responses, some of the spread of the response of the Hadley cell edge and eddy-driven jet position across models may be attributable to this variability in the deep tropical response. Work to assess whether this is true in fully coupled CMIP5 experiments is ongoing. Another factor to consider is the prevalence of the double-ITCZ bias across comprehensive models. The idealized aquaplanet experiments analyzed here suggest that the sensitivity of the ITCZ to surface temperature increases is highest for a particular double-ITCZ configuration, obtained with the GFDL-AM2.1 model with the QOBS SST profile. Although the response is somewhat muted using a slab ocean configuration (Table 2), this does indicate that it is possible that comprehensive models may be overly sensitive in terms of their tropical responses of precipitation if they are simulating overly wide (i.e., double) ITCZs. Furthermore, our results suggest that the varying responses of both the ITCZ width and the Hadley cell strength are nonlinearly dependent on the control state. Again, it would be worth testing whether this holds across coupled models with realistic topography.

A caveat of this work is that it focuses on simulations forced by perpetual equinoctial, that is, hemispherically 
symmetric, conditions. The observed Hadley circulation has a strong seasonal cycle and through much of the year does not exhibit the purely antisymmetric state one would expect with permanent equinoctial forcing (Lindzen and Hou 1988; Dima and Wallace 2003). In practice, this means that apparent changes in annual-mean ITCZ width could arise from changes in the amplitude of the seasonal cycle of ITCZ shifts, not changes in the width of the ascent during any particular season. Thus, when examining models that include a seasonal cycle, or observations, it would be necessary to examine the dynamics of individual seasons in addition to the annual mean. Furthermore, in individual seasons, shifts in the position of the ITCZ can cause changes in the angular momentum budget of the tropical atmosphere, and hence Hadley cell extent, in a similar fashion to the width changes discussed in this work (Kang and Lu 2012; Hilgenbrink and Hartmann 2018).

Because of the hemispheric asymmetry in energy input to the atmosphere in current Earth's climate, the mean position of the ITCZ is in the Northern Hemisphere instead of being centered on the equator (Frierson et al. 2013; Marshall et al. 2014). Shifts in the position of the ITCZ are a dominant response to many different forcings that alter the hemispheric energy balance (e.g., Chiang and Bitz 2005; Hwang et al. 2013). This is distinct from the hemispherically symmetric boundary conditions imposed in both our specified SST and slab ocean experiments, in which the ascent is constrained to be symmetric about the equator, and changes in the width of the ascent are the dominant response to global warming. In the real world, changes in the hemispheric energy balance under global warming may force shifts in the position of the ITCZ in addition to changes in its width. However, as stated above, the ITCZ moving closer to or farther from the equator can have analogous impacts onto the momentum budget of the upper troposphere in the tropics as width changes. Specifically, if the mean position of the ITCZ were to move even farther from the equator under warming (e.g., Seo et al. 2017), this may have the effect of increasing the Hadley cell expansion compared to what would occur with the ITCZ shift.

This work focuses on the zonal-mean changes of the atmospheric circulation. In reality, tropical precipitation has a strong zonally asymmetric component, and El Niño signal that we have used as an example of ITCZ contraction is highly asymmetric in the zonal direction. Thus, there may be additional effects on the higherlatitude circulation due to zonally asymmetric effects such as a weakening of the Walker circulation (Vecchi and Soden 2007). Furthermore, as discussed in the introduction, both ITCZ narrowing and Hadley cell strengthening can play a role in moderating the expansion of the Hadley cell and the eddy-driven jet shift under warming. Recent work examining comprehensive coupled models has found that the multimodel median indicates a narrowing and slight weakening of the ITCZ under global warming (Byrne et al. 2018). In addition, there is a strong correlation between the degree of narrowing and strengthening expected (models with more narrowing tend to have more strengthening). Thus, it would be helpful to know which mechanism is more important. However, it is difficult to disentangle the impacts of a narrowing ITCZ from a strengthening overturning circulation in the experiments performed in this study because there is a strong relationship between the width and strength changes: The cases with most ITCZ narrowing $\left(\left|\Delta T_{\text {eq }}\right|<0.25 \mathrm{~K}\right)$ are those with most strengthening (Fig. 7). A different approach would be required to separate these effects.

Future work will examine the connection between ITCZ width or position and Hadley cell extent across comprehensive climate model ensembles. Previous work has found a connection across CMIP3 models: Those in which the ITCZ shift farther from the equator under global warming tended to have larger Hadley cell expansion (Kang and Lu 2012). As discussed in section 5 , in the idealized aquaplanet simulations shown in Fig. 1, there is a correlation between the response in ITCZ width $\phi_{\text {itcz }}$ and Hadley cell edge $\phi_{\mathrm{hc}}$ to the $+4 \mathrm{~K}$ perturbation across the eight models $(r=0.71)$, but its value is dependent on the inclusion of the GFDL-AM2.1 model that has the most ITCZ narrowing and smallest Hadley cell expansion of all models. Whether modern coupled comprehensive models that include a seasonal cycle exhibit such a connection is under investigation.

Acknowledgments. O. W. was supported by the NOAA Climate and Global Change Postdoctoral Fellowship Program, administered by UCAR's Cooperative Programs for the Advancement of Earth System Science. D. M. W. F. was supported by National Science Foundation Grant AGS-1665247. The authors thank Spencer Hill and two anonymous reviewers for insightful comments that significantly improved the manuscript. O. W. thanks Aaron Donohoe, Casey Hilgenbrink, Isla Simpson, and Robb Wills for helpful discussions on this work.

\section{REFERENCES}

Adam, O., T. Bischoff, and T. Schneider, 2016: Seasonal and interannual variations of the energy flux equator and ITCZ. Part I: Zonally averaged ITCZ position. J. Climate, 29, 3219-3230, https://doi.org/10.1175/JCLI-D-15-0512.1.

Adames, Á. F., and J. M. Wallace, 2017: On the tropical atmospheric signature of El Niño. J. Atmos. Sci., 74, 1923-1939, https://doi.org/10.1175/JAS-D-16-0309.1. 
Allen, R. J., A. T. Evan, and B. B. B. Booth, 2015: Interhemispheric aerosol radiative forcing and tropical precipitation shifts during the late twentieth century. J. Climate, 28, 8219-8246, https://doi.org/10.1175/JCLI-D-15-0148.1.

Anderson, J. L., and Coauthors, 2004: The new GFDL global atmosphere and land model AM2-LM2: Evaluation with prescribed SST simulations. J. Climate, 17, 4641-4673, https://doi.org/ 10.1175/JCLI-3223.1.

Barnes, E. A., and D. L. Hartmann, 2011: Rossby wave scales, propagation, and the variability of eddy-driven jets. J. Atmos. Sci., 68, 2893-2908, https://doi.org/10.1175/JAS-D-11-039.1.

_ _ and L. Polvani, 2013: Response of the midlatitude jets, and of their variability, to increased greenhouse gases in the CMIP5 models. J. Climate, 26, 7117-7135, https://doi.org/10.1175/ JCLI-D-12-00536.1.

- D. L. Hartmann, D. M. W. Frierson, and J. Kidston, 2010: Effect of latitude on the persistence of eddy-driven jets. Geophys. Res. Lett., 37, L11804, https://doi.org/10.1029/ 2010 GL043199.

Bischoff, T., and T. Schneider, 2014: Energetic constraints on the position of the intertropical convergence zone. J. Climate, 27, 4937-4951, https://doi.org/10.1175/JCLI-D-13-00650.1; Corrigendum, 31, 927, https://doi.org/10.1175/JCLI-D-17-0784.1.

— tion, and double-ITCZ bifurcations. J. Climate, 29, 2997-3013, https://doi.org/10.1175/JCLI-D-15-0328.1; Corrigendum, 29 , 7167, https://doi.org/10.1175/JCLI-D-16-0514.1.

Butler, A. H., D. W. J. Thompson, and R. Heikes, 2010: The steadystate atmospheric circulation response to climate change-like thermal forcings in a simple general circulation model. J. Climate, 23, 3474-3496, https://doi.org/10.1175/2010JCLI3228.1.

Byrne, M. P., and T. Schneider, 2016a: Narrowing of the ITCZ in a warming climate: Physical mechanisms. Geophys. Res. Lett., 43, 11350-11357, https://doi.org/10.1002/2016GL070396.

mate: Physical mechanisms. J. Climate, 29, 4709-4721, https:// doi.org/10.1175/JCLI-D-15-0767.1.

- A. G. Pendergrass, A. D. Rapp, and K. R. Wodzicki, 2018: Response of the intertropical convergence zone to climate change: Location, width and strength. Curr. Climate Change Rep., 4, 355-370, https://doi.org/10.1007/s40641-018-0110-5.

Ceppi, P., Y.-T. Hwang, X. Liu, D. M. W. Frierson, and D. L. Hartmann, 2013: The relationship between the ITCZ and the Southern Hemispheric eddy-driven jet. J. Geophys. Res. Atmos., 118, 5136-5146, https://doi.org/10.1002/jgrd.50461.

Chen, G., and I. M. Held, 2007: Phase speed spectra and the recent poleward shift of Southern Hemisphere surface westerlies. Geophys. Res. Lett., 34, L21805, https://doi.org/10.1029/ 2007 GL031200.

Chiang, J. C. H., and C. M. Bitz, 2005: Influence of high latitude ice cover on the marine intertropical convergence zone. Climate Dyn., 25, 477-496, https://doi.org/10.1007/s00382-005-0040-5.

Davis, N., and T. Birner, 2017: On the discrepancies in tropical belt expansion between reanalyses and climate models and among tropical belt width metrics. J. Climate, 30, 1211-1231, https:// doi.org/10.1175/JCLI-D-16-0371.1.

Dima, I. M., and J. M. Wallace, 2003: On the seasonality of the Hadley cell. J. Atmos. Sci., 60, 1522-1527, https://doi.org/ 10.1175/1520-0469(2003)060<1522:OTSOTH $>2.0$. CO; 2 .

Frierson, D. M. W., J. Lu, and G. Chen, 2007: Width of the Hadley cell in simple and comprehensive general circulation models. Geophys. Res. Lett., 34, L18804, https://doi.org/10.1029/ 2007 GL031115.
— and Coauthors, 2013: Contribution of ocean overturning circulation to tropical rainfall peak in the Northern Hemisphere. Nat. Geosci., 6, 940-944, https://doi.org/10.1038/ ngeo1987.

Fu, Q., C. M. Johanson, J. M. Wallace, and T. Reichler, 2006: Enhanced mid-latitude tropospheric warming in satellite measurements. Science, 312, 1179, https://doi.org/10.1126/ science.1125566.

Gerber, E. P., S. Voronin, and L. M. Polvani, 2008: Testing the annular mode autocorrelation time scale in simple atmospheric general circulation models. Mon. Wea. Rev., 136, 1523-1536, https://doi.org/10.1175/2007MWR2211.1.

Held, I. M., and Coauthors, 2000: The general circulation of the atmosphere. Proc. 2000 Program in Geophysical Fluid Dynamics, Woods Hole, MA, Woods Hole Oceanographic Institute, 70 pp., https://www.gfdl.noaa.gov/wp-content/uploads/ files/user_files/ih/lectures/woods_hole.pdf.

Hilgenbrink, C. C., and D. L. Hartmann, 2018: The response of Hadley circulation extent to an idealized representation of poleward ocean heat transport in an aquaplanet GCM. J. Climate, 31, 97539770, https://doi.org/10.1175/JCLI-D-18-0324.1.

Hwang, Y.-T., D. M. W. Frierson, and S. M. Kang, 2013: Anthropogenic sulfate aerosol and the southward shift of tropical precipitation in the 20th century. Geophys. Res. Lett., 40, 2845-2850, https://doi.org/10.1002/grl.50502.

Kang, S. M., and J. Lu, 2012: Expansion of the Hadley cell under global warming: Winter versus summer. J. Climate, 25, 83878393, https://doi.org/10.1175/JCLI-D-12-00323.1.

- D. M. W. Frierson, and I. M. Held, 2009: The tropical response to extratropical thermal forcing in an idealized GCM: The importance of radiative feedbacks and convective parameterization. J. Atmos. Sci., 66, 2812-2827, https://doi.org/ 10.1175/2009JAS2924.1.

Kidston, J., and E. P. Gerber, 2010: Intermodel variability of the poleward shift of the austral jet stream in the CMIP3 integrations linked to biases in 20th century climatology. Geophys. Res. Lett., 37, L09708, https://doi.org/10.1029/2010GL042873.

Kushner, P. J., I. M. Held, and T. L. Delworth, 2001: Southern Hemisphere atmospheric circulation response to global warming. J. Climate, 14, 2238-2249, https://doi.org/10.1175/ 1520-0442(2001)014<0001:SHACRT $>2.0$. CO;2.

Lau, W. K. M., and K.-M. Kim, 2015: Robust Hadley circulation changes and increasing global dryness due to $\mathrm{CO}_{2}$ warming from CMIP5 model projections. Proc. Natl. Acad. Sci. USA, 112, 3630-3635, https://doi.org/10.1073/pnas.1418682112.

Lee, S., and H.-K. Kim, 2003: The dynamical relationship between subtropical and eddy-driven jets. J. Atmos. Sci., 60, 1490-1503, https:// doi.org/10.1175/1520-0469(2003)060<1490:TDRBSA > 2.0.CO;2.

Lindzen, R. S., and S. Nigam, 1987: On the role of sea surface temperature gradients in forcing low-level winds and convergence in the tropics. J. Atmos. Sci., 45, 2440-2458, https://doi.org/10.1175/ 1520-0469(1987)044<2418:OTROSS > 2.0.CO;2.

— , and A. Y. Hou, 1988: Hadley circulations for zonally averaged heating centered off the equator. J. Atmos. Sci., 45, 2416-2427, https:// doi.org/10.1175/1520-0469(1988)045<2416:HCFZAH>2.0.CO;2.

Lorenz, D. J., and E. T. DeWeaver, 2007: Tropopause height and zonal wind response to global warming in the IPCC scenario integrations. J. Geophys. Res., 112, D10119, https://doi.org/ 10.1029/2006JD008087.

Lu, J., G. A. Vecchi, and T. Reichler, 2007: Expansion of the Hadley cell under global warming. Geophys. Res. Lett., 34, L06805, https://doi.org/10.1029/2006GL028443; Corrigendum, 34, L14808, https://doi.org/10.1029/2007GL030931. 
Marshall, J., A. Donohoe, D. Ferreira, and D. McGee, 2014: The role of the ocean circulation in setting the mean position of the ITCZ. Climate Dyn., 42, 1967-1979, https://doi.org/10.1007/ s00382-013-1767-z.

McFarlane, A. A., and D. M. W. Frierson, 2017: The role of ocean fluxes and radiative forcings in determining tropical rainfall shifts in RCP8.5 simulations. Geophys. Res. Lett., 44, 86568664, https://doi.org/10.1002/2017GL074473.

Medeiros, B., D. L. Williamson, and J. G. Olson, 2016: Reference aquaplanet climate in the Community Atmosphere Model, version 5. J. Adv. Model. Earth Syst., 8, 406-424, https://doi.org/ 10.1002/2015MS000593.

Möbis, B., and B. Stevens, 2012: Factors controlling the position of the intertropical convergence zone on an aquaplanet. J. Adv. Model. Earth Syst., 4, M00A04, https://doi.org/10.1029/2012MS000199.

Neale, R. B., and B. J. Hoskins, 2000a: A standard test for AGCMs including their physical parameterizations: I: The proposal. Atmos. Sci. Lett., 1, 101-107, https://doi.org/10.1006/asle.2000.0022. , and - 2000b: A standard test for AGCMs including their physical parameterizations: II: Results for the Met Office Model. Atmos. Sci. Lett., 1, 108-114, https://doi.org/10.1006/ asle.2000.0024.

— - and Coauthors, 2012: Description of the NCAR Community Atmosphere Model (CAM 5.0). NCAR Tech. Note NCAR/ TN-486+STR, 274 pp., www.cesm.ucar.edu/models/cesm1.0/ cam/docs/description/cam5_desc.pdf.

Oueslati, B., and G. Bellon, 2013: Tropical precipitation regimes and mechanisms of regime transitions: Contrasting two aquaplanet general circulation models. Climate Dyn., 40, 2345-2358, https://doi.org/10.1007/s00382-012-1344-x.

Randel, W. J., and I. M. Held, 1991: Phase speed spectra of transient eddy fluxes and critical layer absorption. J. Atmos. Sci., 48, 688-697, https://doi.org/10.1175/1520-0469(1991) 048<0688:PSSOTE $>2.0 . \mathrm{CO} ; 2$.

Retsch, M. H., C. Hohenegger, and B. Stevens, 2017: Vertical resolution refinement in an aqua-planet and its effect on the ITCZ. J. Adv. Model. Earth Syst., 9, 2425-2436, https://doi.org/ 10.1002/2017MS001010.

Rose, B. E. J., and D. Ferreira, 2013: Ocean heat transport and water vapor greenhouse in a warm equable climate: A new look at the low gradient paradox. J. Climate, 26, 2117-2136, https://doi.org/10.1175/JCLI-D-11-00547.1.

Rotstayn, L. D., M. A. Collier, and J.-J. Luo, 2015: Effects of declining aerosols on projections of zonally averaged tropical precipitation. Environ. Res. Lett., 10, 044018, https://doi.org/ 10.1088/1748-9326/10/4/044018.

Santer, B. D., and Coauthors, 2003: Contributions of anthropogenic and natural forcing to recent tropopause height changes. Science, 301, 479-483, https://doi.org/10.1126/science.1084123.

Satoh, M., 1994: Hadley circulations in radiative-convective equilibrium in an axially symmetric atmosphere. J. Atmos. Sci., 51, 1947-1968, https://doi.org/10.1175/1520-0469(1994)051<1947: HCIREI $>2.0 . \mathrm{CO}$;2.
Seager, R., N. Harnik, Y. Kushnir, W. Robinson, and J. Miller, 2003: Mechanisms of hemispherically symmetric climate variability. J. Climate, 16, 2960-2978, https://doi.org/10.1175/ 1520-0442(2003)016<2960:MOHSCV > 2.0.CO;2.

Seidel, D. J., and W. J. Randel, 2007: Recent widening of the tropical belt: Evidence from tropopause observations. J. Geophys. Res., 112, D20113, https://doi.org/10.1029/2007JD008861.

—, Q. Fu, W. J. Randel, and T. J. Reichler, 2008: Widening of the tropical belt in a changing climate. Nat. Geosci., 1, 21-24, https://doi.org/10.1038/ngeo.2007.38.

Seo, J., S. M. Kang, and T. M. Merlis, 2017: A model intercomparison of the tropical precipitation response to a $\mathrm{CO}_{2}$ doubling in aquaplanet simulations. Geophys. Res. Lett., 44, 993-1000, https://doi.org/10.1002/2016GL072347.

Simpson, I. R., and L. M. Polvani, 2016: Revisiting the relationship between jet position, forced response, and annular mode variability in the southern midlatitudes. Geophys. Res. Lett., 43, 2896-2903, https://doi.org/10.1002/2016GL067989.

_ T. A. Shaw, and R. Seager, 2014: A diagnosis of the seasonally and longitudinally varying midlatitude circulation response to global warming. J. Atmos. Sci., 71, 2489-2515, https://doi.org/10.1175/JAS-D-13-0325.1.

Taylor, K. E., R. J. Stouffer, and G. A. Meehl, 2012: An overview of CMIP5 and the experiment design. Bull. Amer. Meteor. Soc., 93, 485-498, https://doi.org/10.1175/BAMS-D-11-00094.1.

Vecchi, G. A., and B. J. Soden, 2007: Global warming and the weakening of the tropical circulation. J. Climate, 20, 43164340, https://doi.org/10.1175/JCLI4258.1.

Voigt, A., and T. A. Shaw, 2015: Circulation response to warming shaped by radiative changes of clouds and water vapour. Nat. Geosci., 8, 102-106, https://doi.org/10.1038/ngeo2345.

_ , and Coauthors, 2016: The tropical rain belts with an annual cycle and a continent model intercomparison project: TRACMIP. J. Adv. Model. Earth Syst., 8, 1868-1891, https:// doi.org/10.1002/2016MS000748.

Walker, C. C., and T. Schneider, 2006: Eddy influence on Hadley circulations: Simulations with an idealized GCM. J. Atmos. Sci., 63, 3333-3350, https://doi.org/10.1175/JAS3821.1.

Watt-Meyer, O., and D. M. W. Frierson, 2017: Local and remote impacts of atmospheric cloud radiative effects onto the eddydriven jet. Geophys. Res. Lett., 44, 10 036-10 044, https://doi.org/ 10.1002/2017GL074901.

Williamson, D. L., 2008: Convergence of aqua-planet simulations with increasing resolution in the Community Atmospheric Model, version 3. Tellus, 60A, 848-862, https://doi.org/ 10.1111/j.1600-0870.2008.00339.x.

Wodzicki, K. R., and A. D. Rapp, 2016: Long-term characterization of the Pacific ITCZ using TRMM,GPCP, and ERAInterim. J. Geophys. Res. Atmos., 121, 3153-3170, https:// doi.org/10.1002/2015JD024458.

Yin, J. H., 2005: A consistent poleward shift of the storm tracks in simulations of 21 st century climate. Geophys. Res. Lett., 32 , L18701, https://doi.org/10.1029/2005GL023684. 